\title{
EVALUATION OF METHODS FOR SEISMIC ANALYSIS OF MIXED-OXIDE FUEL FABRICATION PLANTS
}

\author{
F. J. Tokarz, D. F. Arthur, and R. C. Murray
}

October 8, 1975

Prepared for U.S. Energy Research \& Development

Administration under contrast No. W-7405-Eng-48

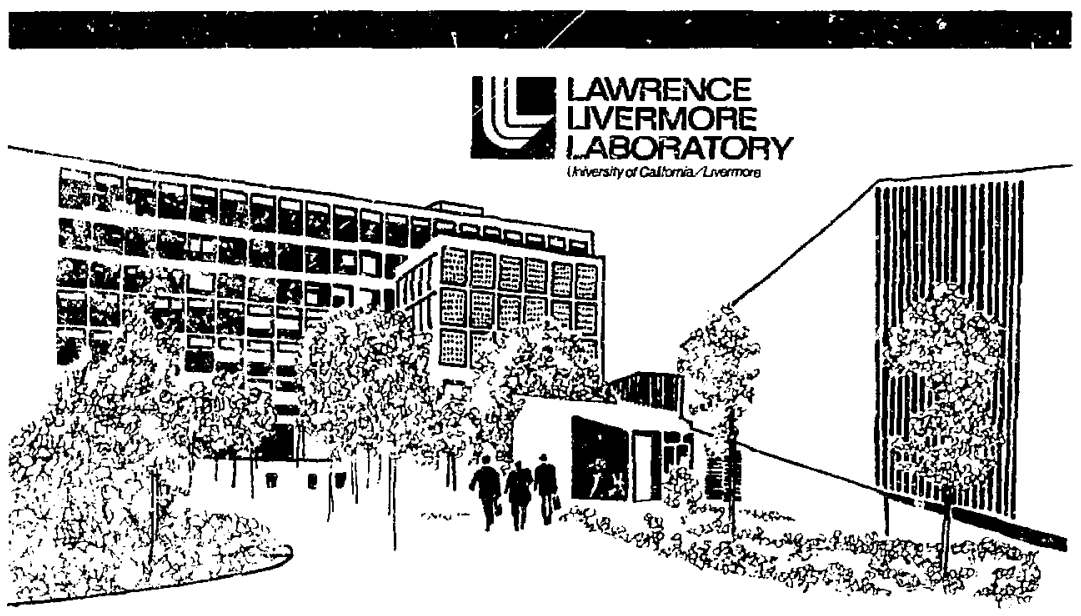

. $\because 20 \%$ 
NOTICE

"This repont wos prepared as an account of work sponsored by the United States Gavemment. Nejther the Unifed Sintes nor the United Sotes Energy Research \& Development Administration, nor any of theit employees, nor any of their contractors. subcontsactors, or their employees, makes an. warsanty, express of implied, or assumes any 'eraj liability or responsibitity for the ncrutacy, completeness or usefulness of any intormation, apporatus, product or process disclosed, or represents that its use would not inteinge privately-owned right.."

\section{Printed in the United States of America Available from \\ National Technical Information Service U. S. Department of Commerce 5285 Port Royal Road \\ Springfield, Virginia 22151}

Price: Printed Copy $\$$; Microfiche $\$ 2.25$

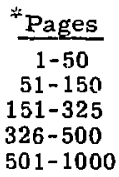

NTIS

Selling Price

$\$ 4.00$

$\$ 5.45$

$\$ 7.60$

$\$ 10.60$

$\$ 13.60$ 
Dijtribution Category

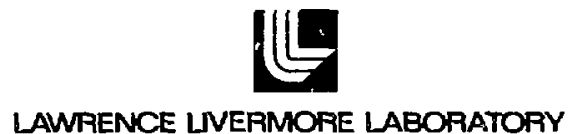

University of Caffomia Livemore, Calforria 94550

UCRL-51928

\section{EVALUATION OF METHODS FOR SEISMIC ANALYSIS OF MIXED-OXIDE FUEL FABRICATION PLANTS}

F. J. Tokarz, D. F. Arthur, and R. C. Murray

MS. dare: October i, 1975

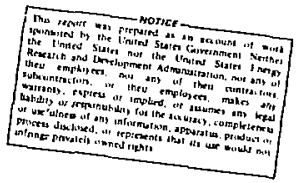




\section{Contents}

Abstract . . . . . . . . . . . . . . . . . . . . . . . 1

Sumary and Recomnendations .... . . . . . . . . . . . . . . . 1

Critical structures and Equipment . . . . . . . . . . . . . . . . 4

Manufacturing Bullding . . . . . . . . . . . . . . . . . . 7

Recelving and Drum Storage . . . . . . . . . . . . . . . . 8

Unloading Station and Scrap Recovery System . . . . . . . . . . . . . 8

Bulk Storage and Mixed-oxide Storage . . . . . . . . . . . . . . 8 8

Blending, C.lumn and Pressing Column . . . . . . . . . . . . . . . 10

Transfer Systen . . . . . . . . . . . . . . . . . . . . 10

Ventilation System. . . . . . . . . . . . . . . . . . . . . 11

Diesel Generators .. . . . . . . . . . . . . . . . . . 11

Instrumentation . . . . . . . . . . . . . . . . . . . . . . 11

Methods of Strictural Analysis . . . . . . . . . . . . . . . . 12

Manufacturing Bullding . . . . . . . . . . . . . . . . . . . . 12

Equipment . . . . . . . . . . . . . . . . . . . . . . . 14

Definition of Terms . . . . . . . . . . . . . . . . . 15

Ava1lable Methods . . . . . . . . . . . . . . . . . . . 22

Comparison of Methods . . . . . . . . . . . . . . . . . . 28

Conclusions . . . . . . . . . . . . . . . . . . . . 34

Generation of Floor Spectra . . . . . . . . . . . . . . . . . 36

Floor-Spectra Calculations . . . . . . . . . . . . . . . . 37

Ground Motion Used ... . . . . . . . . . . . . . . 37

Bullding Models . . . . . . . . . . . . . . . . . 37

Time-History Method . . . . . . . . . . . . . . . . . 41

Approximate Methods . . . . . . . . . . . . . . . . . . 42

Comparison of Methods . . . . . . . . . . . . . . . . . 52

Floor Spectra . . . . . . . . . . . . . . . . . . . 52

Intanglbles . . . . . . . . . . . . . . . . . . . . 53

Conclusions . . . . . . . . . . . . . . . . . . . . . . 57

Acknowledgments . . . . . . . . . . . . . . . . . . . . 57

References . . . . . . . . . . . . . . . . . . . . . . . . 58

Appendix. Description of the Kapur and Biggs Approximate Methods . . . 60 


\title{
EVALUATION OF METHODS FOR SEISMIC ANALYSIS OF MIXED-OXIDE FUEL FABRICATION PLANTS
}

\author{
Abstract \\ Gu1delines are needed for select- \\ ing appropriate rethods of structural \\ analyses to evaluate the seisuic \\ vazard of mixed-oxide fuel fabrication \\ plants. Tr.is study examines the \\ different available methods and their \\ applicability to fabricacion plants. \\ Our results should provide a basis \\ for establishing guidelines recommend- \\ ing methods of analysis to ensure safe \\ design against seismic hazards. \\ Using the Westinghouse Recycle \\ Fuels Plant as representative of \\ future mixed-oxide fuel fabrication \\ plants, we Identified critical \\ structures and equipment (systems, \\ components, and piping/ducting). \\ Tnese included the manufacturing \\ building and 11 different pieces of \\ equipment. After examination of the \\ dyaamic response characteristics of \\ the building and the different \\ methods available to analyze equ1p- \\ ment, we recommenc appropriate \\ wethods of analyses. \\ Because critical equipmerit \\ analysis and test methods generally \\ use floor-response spectra as their \\ seismic input loading, we also \\ examined several metnods used to \\ generate floor spectra. Tnese \\ include the time-history approach and \\ the Kapur and BIggs approximate \\ methods. Dur examination included \\ the effect of site characteristics \\ and both hortzontal and vertical \\ structural response.
}

\section{Summary and Recommendations}

This is the final report of a Lawrence Livermore Laboratory study requested and Eunded by the U.S. Nuclear Regulatory Commissior, Office of Standards Development. The report is submitted to NRC in fulfillment of tnat request and funding.
Guidelines are needed to specify methods of structural analys is that ensure safe earthquake design of nuclear fuel fabrication facilities. The objective of this study is to compare the methods of structural analysis available for seismic design 
of nuclear fuel fabrication plants. The results may be used as the basis of a Regulatory Guide that recommends the method or methods of analysis to ensure safe structural design. The scudy is restricted to fuel fabrication structures and equipment defined to be critical, that is, structures and eg'tipment whose failure could cause substantial radioactive hazard to the public.

Tu reach this objective we identifled critical fuel fabrication plant structures and equipment. The Westinghouse Recycle Fuels Plant was selected to be representative of fucure fuel fabrication plants. Our review of this plant pointed to 11 items (listed in Table 2) as critical. We include a description of each critical 1tem, its function, and its location within the manufacturing bullding.

The next step was to determine the method of seismic analysis appropriate for each 1tem. Our recommendation for the manufacturing bullding is based on the results of a study recently completed for NRC and is shown in Table 1 . In selecting methoc's of analysis for equipment, we evaluated 11 different approaches. We found that the choice of method depended heavily on the response characteristics of both the equipment and its support structure (iu tnis case, the nanuiacuring building). lable 3 sunumizizes the difierent methods of equipment analysis and Table 1 summarizes our recommendations for critical equipuent analysis.

In the section Generitiun $0^{\circ}=Z_{0}$ Syeutia, we evaluate methods of calculating floor spectra for tuel fabrication plants. The choice of methods is important, because floor spectra will normally be required during the design of future mixedoxide fuel fabrication plants (MUFF''s). A dynamic tiale-nistory analysis of the bullding is the most coimon approach used to calculate floor spectra. however, alternate approximate methods have been suggested by both Kapur and Biggs. We generated and compared horizontal and vertical MOFFF Eloor spectra by all three methods. Our comparison indicates that although the apprcximate methods could be mate acceptable from a safecy standpoin:, they would be overly conservative. The timehistory method will yield floor spectra that are less uncertain and less conservative for a relatively modest additional effort. We recommend the time-history approach for developing MOFFP floor spectra. 
Table 1. Reconmended methods of analysis for manutacturino, butlding and critical equipment.

\begin{tabular}{|c|c|c|c|}
\hline & $\begin{array}{l}\text { Kecommended method } \\
\text { of analysis }\end{array}$ & $\begin{array}{l}\text { Recommended } \\
\text { model }\end{array}$ & $\begin{array}{l}\text { Input } \\
\text { loading }\end{array}$ \\
\hline \multicolumn{4}{|c|}{ Janufacturing building } \\
\hline $\begin{array}{l}\text { Founded near or } \\
\text { at grade }\end{array}$ & $\begin{array}{l}\text { Dynamic } \\
\text { (response } \\
\text { spectra) }\end{array}$ & $\begin{array}{l}\text { Lumped mass } \\
\text { or finite } \\
\text { element }\end{array}$ & $\begin{array}{l}\text { G:ound-response } \\
\text { s pectrum or } \\
\text { a:celeration } \\
\text { t Lme-history }\end{array}$ \\
\hline $\begin{array}{l}\text { Deeply embeduled } \\
\text { (embedded depti } \\
>15 \% \text { of least } \\
\text { foundation } \\
\text { dimension) }\end{array}$ & $\begin{array}{l}\text { Dynamic } \\
\text { (response } \\
\text { spectra) }\end{array}$ & $\begin{array}{l}\text { Finice } \\
\text { element }\end{array}$ & $\begin{array}{l}\text { Ground-response } \\
\text { spectrum or } \\
\text { cceleration } \\
\text { ime-history }\end{array}$ \\
\hline $\begin{array}{l}\text { Criclcal ecuipment } \\
\text { higid } \\
(f>3 ; \mathrm{Hz})\end{array}$ & Statice & $-\ldots--^{d}$ & $\begin{array}{l}\text { Laximum floor } \\
\text { acceleration }\end{array}$ \\
\hline $\begin{array}{l}\text { flexible } \\
(\mathrm{f}<33 \mathrm{~Hz})\end{array}$ & $\begin{array}{l}\text { Dynamic } \\
\text { (response spectra } \\
\text { or time-nistory)c }\end{array}$ & $\begin{array}{l}\text { Lumped mass } \\
\text { or finite } \\
\text { elenent }\end{array}$ & $\begin{array}{l}\text { Floor-response } \\
\text { spectrum or } \\
\text { acceleration } \\
\text { time-history }\end{array}$ \\
\hline Heavy $^{e}$ & $\begin{array}{l}\text { Jynamic } \\
\text { (response spectra } \\
\text { or time-hLstory) }\end{array}$ & $\begin{array}{l}\text { Lumped mass } \\
\text { or finite } \\
\text { element } \\
\text { (coupled } \\
\text { building- } \\
\text { equipment } \\
\text { model) }\end{array}$ & $\begin{array}{l}\text { Grourd-response } \\
\text { spectrum or } \\
\text { acceleration } \\
\text { time-ristory }\end{array}$ \\
\hline
\end{tabular}

If time-histoity-response quantities and thelr phasis relationsinip are required, a time-history analysis by elther modal or direct integration must be perfurmed. If nonlinear effects are considered Imprirtant, a time-history analysis by direct integration must be performed.

For layered and shallow sites, use of a lumped-mass model with soil springs maly uot be accurate.

If differential support motion need b? considered for equipment, a dynamic analysis, elther coupled (bullding-equipment) or uncoupled, must be performed.

alstrlbute loads per mass distribution. Nodel should reflect stifiness of actual structure.

e coupled model includes both the equipment and the supporting structure. Crlterla for decoupling equipment from supporting strdcture are

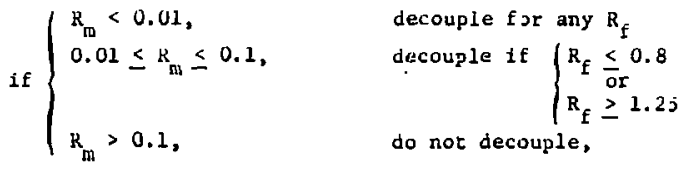


where $\begin{aligned} k_{m} & =\frac{\text { mass of equipment }}{\text { mass of supporting structute }} \text { and } \\ k_{f} & =\frac{\text { natural frequency of equipment }}{\text { frequency of dominant suppurt motion }} .\end{aligned}$

\section{Critical Structures and Equipment}

We cirose to study the Westinghouse Kecycle Fuels Planc, to be located in Anderson, South Carolina. The capacity of the Westinginouse plant is typical of those expected for future mixed-oxide fuel fabrication plants, that is, an ultimate production of about 1 metric con/d of fuel in fuel rod form. We consider the planned process flow equipment, piping, and structures to be representative and inclusive of equipment and structures anticipated in future commerclal-scale fuel fabrication plants.

Tne Euel received ac HUFF' $s$ is expected to be In the form of plutonium and uranium oxide powders. Fuel elements produced from these oxides will be used in lfght-watercooled reactors.

The future Wforp is assumed to be composed of a manufacturing bullding and structures housing auxiliary functions. The manufacturing buildIng wall house powder process operations and safecy-related 1tems that must remain functional during the stanidard maximum credible accioents, such as tornadoes and earthquakes.

It is further assured that the plutoniuin and plutonium-uranium mixtures will wot be alrectly nandlet. A remute, automatic process and appropriate snlelds and confinenent will be necessary. Thus, it is assumed that processing will be performed in a "canyon" Lapable of withstanding the design eartiquake. Equiptient critical to sate operation must also withstand tine Jesign earthquake.

Table 2 lists those structures and equipment we consider critical. For purposes of analysis, we have assumed that the failure of any $c . \bar{f}$ these structures or components could lead to a substantiai radioac:ive hazard to the general public. It should be noted tnat these cr.tical items are associated with the fairication process when t'je pluconium as.t uranium oxides are in powder form. Systems and components for subsequently processing fuel pellets are not considered to be critical. 
Table 2. WUFEP iritical structires and equipment.

\begin{tabular}{|c|c|c|}
\hline $\begin{array}{l}\text { Uuter continement } \\
\text { structure }\end{array}$ & $\begin{array}{l}\text { Process } \\
\text { equipment }\end{array}$ & $\begin{array}{l}\text { Auxiliary } \\
\text { systems }\end{array}$ \\
\hline \multirow[t]{5}{*}{$\begin{array}{l}\text { danufacturing } \\
\text { building }\end{array}$} & $\begin{array}{l}\mathrm{PuO}_{\llcorner} \text {receiving and } \\
\text { drum storage }\end{array}$ & $\begin{array}{l}\text { Powder transfer } \\
\text { system }\end{array}$ \\
\hline & $\mathrm{PLO}_{2}$ unloading station & Scrap recovery system \\
\hline & $\begin{array}{l}\mathrm{PuO}_{2} \text { bulk storage tanks } \\
\text { Blending column }\end{array}$ & $\begin{array}{l}\text { Vencilation system } \\
\text { exhaust (piring and } \\
\text { Einal HEPA bank) }\end{array}$ \\
\hline & $\begin{array}{l}\text { Hixed-oxide storage } \\
\text { tanks }\end{array}$ & Diesel generators \\
\hline & Pressing column & $\begin{array}{l}\text { Instrumentation } \\
\text { system }\end{array}$ \\
\hline
\end{tabular}

The following sources of information were used to develop this list:

(1) the License Application for the Westlnghouse Recycle Fuels Plant ${ }^{1}$;

(2) discussions with Ralph 4 . Parsons Company enginters, designers of the plant; (3) discussions with Battelle Pacilic Jorthwest Laboratorles personnel regarding alrborne release of plutonium from generic mixedoxide plants ${ }^{2}$; and (4) discusstons with Regulacory sta:f. These discussions permitted us to study alternative bullding deslgns, systems, and componencs for fucure plancs.

Flgure 1 shows the manufacturing building plan of the Westinghouse plant. The plutoniun and uranium extde powders are recelved at the plant in drum containers (I). After initial storage the containers are moved to unloading stations (2) where the oxide powders are transferred to the buik storage bins (3). The powders are then taken frow the bins in weighed amouncs, mixed in $a$ blending colur", (4), and sent to the mixed-oxide storage area (5). The properly blended mixec oxide is then compacted, granulated, and pressed lato pellets in the pressing column (6). The final operation involves sinterling, grinding, cleatirig of rod hardware, and loading the pellets into fuel rods. (See Refs, 1 and 2 For more detailed information.)

The transfer and scrap recovery systems associated witi the mixedoxide powder operacton are also considered critical. The transfer systems are assumed to be prematic. The scrap recovery system w111 gather mixed-oxide scrap and recycle $1 t$. 


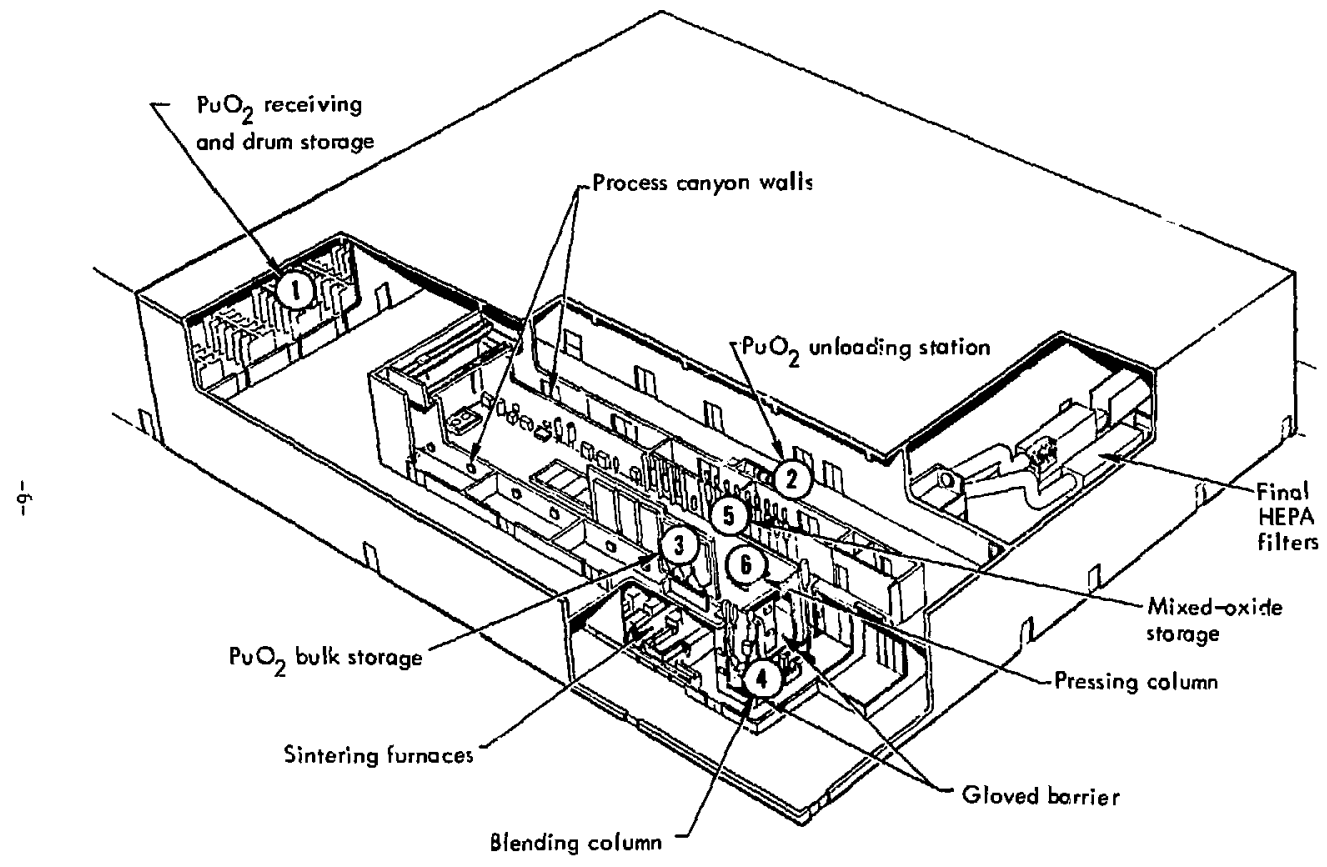

Fig. 1. Nanufacturing bullding of Westinghouse Kecycle Fuels Plant. 
Parts of tiat ventilation systet. are diso considereid critical. Inis system will filter tac air catering and Leaving the process area to infinitize the relsase of airborise oxide parcliles irom the buliding.

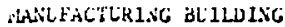

Uus sclectlon of apropriate methods of seisculc anz..ysts of the manufacturling bullding is based on Refs. 3 and 4 . Justification for our recummendations is concained in Rei. 4 and will not be repeated here.

Flgure 2 shows the key structural elements of a represeritative manufacturing building. The buflding is approximately $210 \mathrm{ft}$ square with 18-in.-thick reinforced coucrete roof, ilours, and exterior walls. The ground floor is at grade, the secund floor $20 \mathrm{ft}$ above grade, and the roof $50 \mathrm{ft}$ above grade.

The vertical load-carrying system consists of slabs spanning supporting edge beams that bear on 2- $\times 2-f t$ columns on 30-ft centers each way. At end bays, the extertor walls act as bearing wa11s.

The laceral focce-resisting system consists of floor and roof slabs and exterior shear walls. The slabs act as rigld concrete diaphragms spanring the shear walls, which
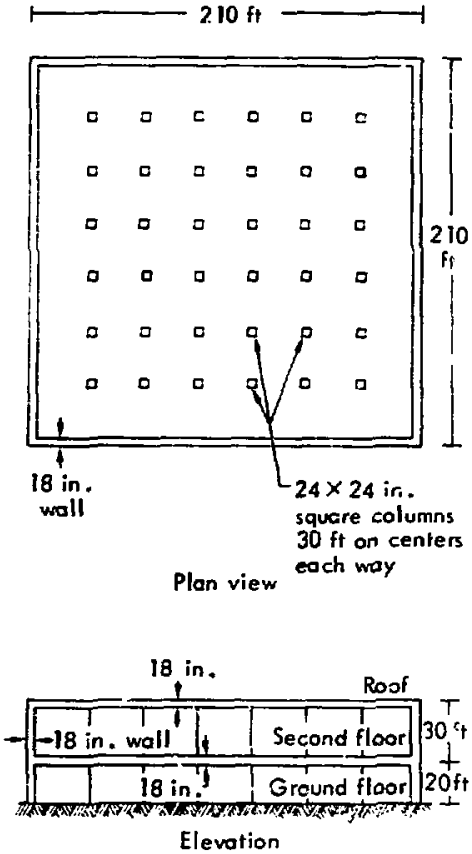

Fig. 2. :ianuíazuriab builaing.

transmit the loads to the ioundation. End walls perpendicular to the djrection of laceral load and interior columns were assumed to provide negliglbie lateral resistance.

In our mael the incertor canyon walls are trjated as partitton walls and are not considered part of either the vertical or lateral forceresisting systems. 
External structural design of this manufacturing building was governed primarily by tornado considerations. ${ }^{3}$ Many future recycle plants will be located east of the continental divide near fuel reprocessing plants and nuclear power reactors, and these butldings will have their external structural designs governed by Region I tornado criteria. 5,6 The destgn of floors and columns will be governed by selsmic criteria. Similarly, the 1.5-ft-thick floor slab was governed by seismic loading to equipment. External structure design of future fuel recycle plants located west of the continental divide may or may not be governed by tornado loading.

\section{RECEIVING AND DRUM STORAGF}

Plutonium oxide is received and stored in spectally designed ${ }^{7}$ double shipping containers in the receiving and drura storage area. The outer container is stmilar to a 55-gal drum. The inner container is a thick-walled tube closed on one end and sealed on the other with a heavy, bolted $11 \mathrm{~d}$. The inner container is centered in the outer container and is surrounded by packing material. The oxtde powder is located in two sealed cans inside a thin-walled vessel within the inner contajner.
Design of the complete container is controlled by handling and transportation loading, which far exceeds seismic loading.

\section{UNLOADING STATION AND SCRAP RECOVERY SYSTEM}

The shipping containers are mechanically transferred to the unloading station. After the lid and packfng material are removed the open shippir; container is placed in a glove box enclosure and the powder is unloaded. Glove boxes are also used to enclose all waste reprocessing.

Figure 3 shows a representative glove-box design. The glove box is constructed of 12-gauge stainless steel with a 3/8-in. shatterproof glass window. It is $2-1 / 2 \times 3-1 / 2$ $\times 8 \mathrm{ft}$ and weighs $50001 \mathrm{~b}$. The glove boxes are assumed fastened to a structural steel support frame anchored to the main building structure.

\section{BULK STORAGE AND MIXED-OXIDE} STORAGE

Prior to the blending operacions the plutonium oxide powder is temporarily stoced in bulk stocage bias. These bins are designed to recelve powder from the transfer system, are geometrically safe, and permit powder weighing. After blend- 


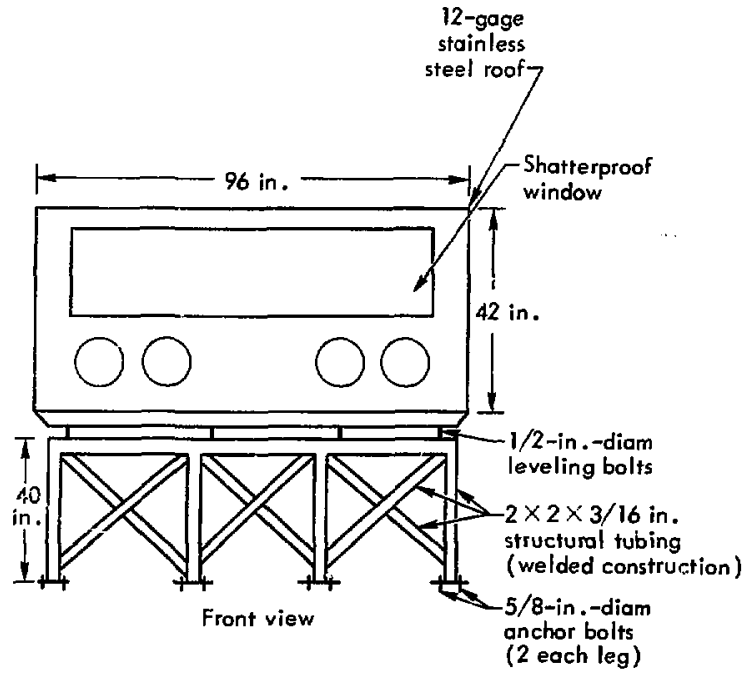

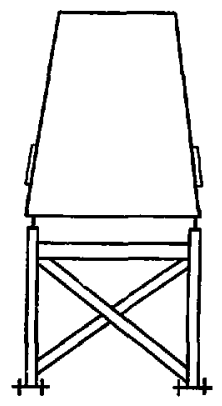

End view

+-30 in.-1

Fig. 3. Glove box (5000 lb).

ing, the nixed-oxide powder is stored In similar bins until transfer to the pressing column.

Figure 4 shows a representative storage bin design. The bin is approximately $8 \mathrm{ft}$ high, 8 ft wide, and $4 \mathrm{in}$. thick and is constructed of 1/4-in. stainless steel plate. We supported the bin by two seats and provided four braces for lateral support. The weight of the bin and

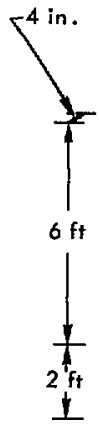
powder is estimated at $15001 \mathrm{~b}$.

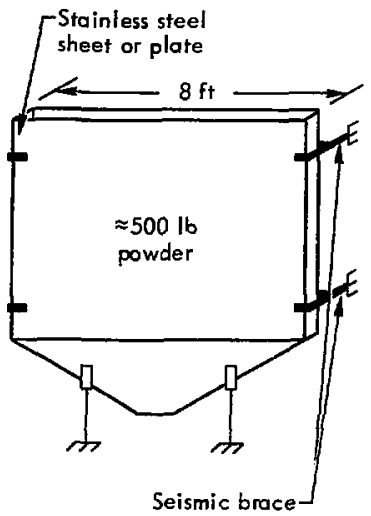

Fig. 4. Storage bin. 
BLENDING COLLNA AND PRESSING COLURA

The blending and pressing columns are an assembly of equipmen: arranged to perform a common operation. It is likely that arrangement and selection of equipment in future designs will vary considerably. For thia reason we will not conduct structural response calculations to evaluate and recommend the most appropriate method of analysis for the columns. We consider, however, that both the blending and pressing columas are subsystems and require a dyaamtc analysis. This approach follows the same gutdelines used for critical subsyatems in power plants.

Both the blending and pressing columns are enclosed by gloved barriers (a barriers), shown in Fig. 5. They are constructed of 101n.-thick reinforced concrete and extend from the flrst-floor level to the second-floor level. They are $5-1 / 2 \times 8-1 / 2$ ft in plan, and they are attached to the matn butlding gtructure at both floor levels.

\section{TRANSFER SYSTEM}

The Westinghouse plant wilı use a pneumatic (vacuum) system to transfer the oxide powders. Future designs could use mechantcal systems for transfer, but we consider the

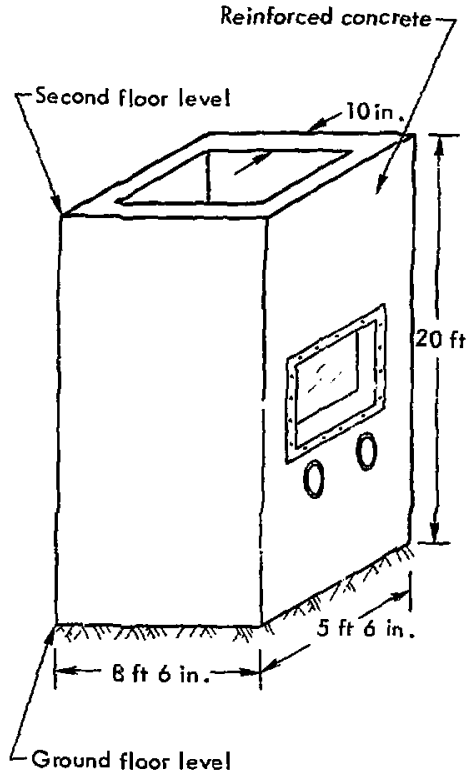

Fig. 5. Gloved barrier.

preumatic transfer system as represeatative for this study.

The preumatic lines are assumed to be schedule-40 stainless steel oide ${ }^{*}$ with a maximum 6-ia. diameter and 0.28-in. wall thickness. The pneumatic system will be used to transfer the

\footnotetext{
The schedule number is not a structural term but refers to the pressure-stress ratto of pipe. For further information see American Standard ASA B36,10-1959.
} 
powder oxides from the unloading station to the bulk storage bins and also to transfer the blended powder from the blending column to the mixed-oxide storage bins. Storage is assumed to be on an upper level to take advantage o $o^{2}$ gravity feed for blending and pressing operations.

\section{VENT ILATION SYSTEM}

The ventilation system will employ high-efficlency particulate air (HEPA) filters to minimize the release of airborne oxides from the building. The system will always direct the air flow towards zones of greater radioactive contamination potentlal. Separate HEPA filters are provided for glove boxes, gloved barriers, and work rooms. Alr is filtered when it enters the building, when 1 t enters glove boxes and gloved barriers, when it leaves the glove boxes and gloved barrlers, when it leaves work areas, and when it leaves the bullding through a final HEPA filter bank.

For seismic considerations three parts of the ventilation system are important: the exnaust ducting, the bax HEPA filters, and the final HEPA filter bank. The ducting will con- sist of approximately 18-in.-diameter, relatively lightweight (16-gauge) pipe. The ducting will be anchored to the main buflding stxucture. The box HEPA filters are lightweight and are approximately a l-ft cube. The final HEPA filter bank consists of a filter frame that houses the box HEPA filters.

Figure 6 shows a HEPA filter frame designed $f \mathrm{n}$ accordance with ORNLNSIC-65 guidelines. 9 The irame is of welded stainless steel construction with dimensions of $1-\times 10-\times 20-\mathrm{ft}$ and a total weight of $2000 \mathrm{lb}$.

\section{DIESEL GENERATORS}

Diesel-driven electrical generators are required as a backup electrical system. They are located on the second floor of the Westinghouse plant.

\section{INSTRUNENTAT ION}

The critical instrumentation consigts of devices that measure and record earthquake ground motion and those that monftor the integrity of the systems confining the oxide powders. 


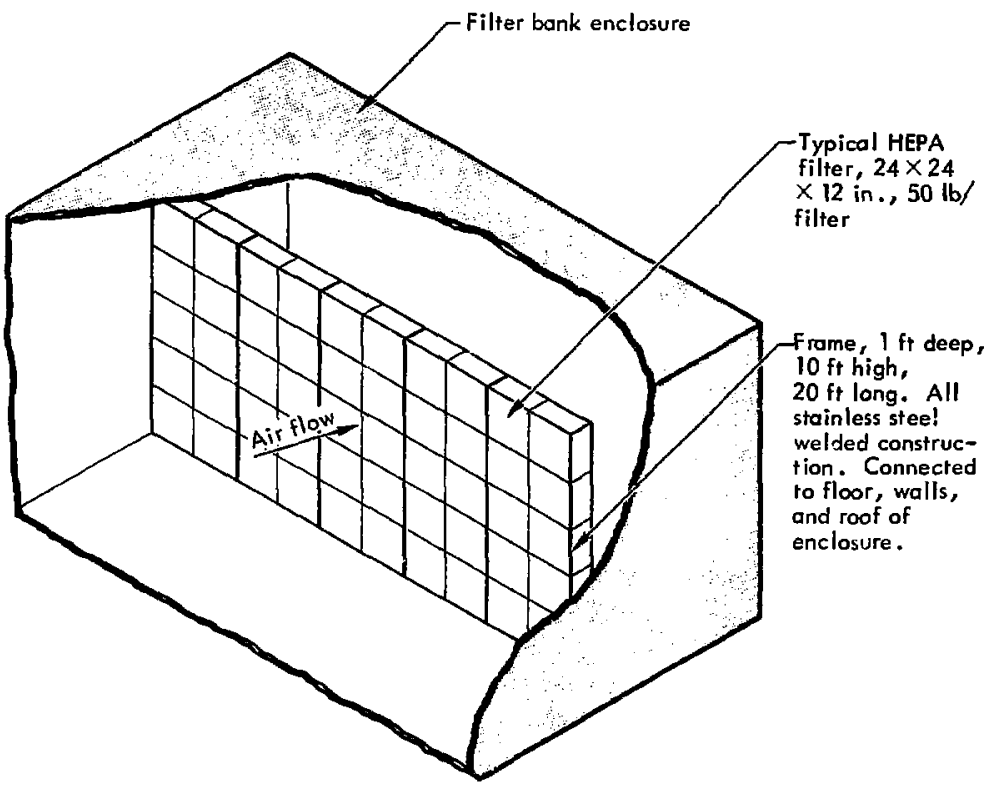

Fig. 6. Final HEPA filters, frame, and enclosure.

\section{Methods of Structural Analysis}

MANUFACTURING BUILDING

We recommend that the manufacturIng bullding for fuel fabrication plants be evaluated against potential selsmic hazard using the guidelines shown in Table 3. These recomnendations are based on the recently completed study "Evaluation of Methods for Seismic Analysis of Nuclear Fuel Reprocessing Plants." 4 The objective of that study was to examine avallable methods of structural analysis to evaluate the earthquake hazard of nuclear fuel reprocessing plants. The conclusions may be used as the basis for a Regulatory Guide that recomends methods of analysts necessary to insure safe design. 
Table 3. kecomnended nodels and rethod of analysis.

\begin{tabular}{|c|c|c|}
\hline $\begin{array}{l}\text { Foundation } \\
\text { location }\end{array}$ & Mode1 & $\begin{array}{l}\text { Stetnod of } \\
\text { analysis }\end{array}$ \\
\hline $\begin{array}{l}\text { Near or at } \\
\text { grade }\end{array}$ & $\begin{array}{l}\text { Lumped mass or } \\
\text { finite elenient }\end{array}$ & $\begin{array}{l}\text { Response } \\
\text { spectraa }\end{array}$ \\
\hline $\begin{array}{l}\text { Deeply } \\
\text { enibedded }\end{array}$ & Finite element & $\begin{array}{l}\text { Response } \\
\text { spectra }\end{array}$ \\
\hline \multicolumn{3}{|c|}{$\begin{array}{l}\text { If time-history response quantities } \\
\text { are required, time-history analysis } \\
\text { by either modal or direct integra- } \\
\text { tion must be performed. If non- } \\
\text { linear effects are important, a } \\
\text { time-history analysis by direct } \\
\text { integration must be performed. }\end{array}$} \\
\hline
\end{tabular}

In Ref. 4 we considered the Barnwell Nuclear Fuel Plant (BNFP) to te representative af future comnercial reprocessing plants and identified eritical structures requiring sefsmic analysis. We then placed these critical structures into four categories of different response characteristics: (1) structures founded near or at grade; (2) structures deeply embedded; (3) structures fully buried; and (4) equipment. After selecting one representative structure in each of the first three categories, we perfomed extensive response calculations using the different methods of analysis. The calculations included static and dynamic methods using lumped-mass and tinite-element models. Responsespectrum, modal, and directIntegration analysis procedures were used, The effects of site characteristics (such as nard, intermediate, and soft) on the response were considered. Regulatory Guide 1.60 was used as the basis for groundmotion input. ' compared the calculational results and the required manpower and computer effort to form the basis for our recommendations. Also included in Ref. 4 were discussions of the avallable methods of analysis for both site response and structural response.

We chose the process building at the BNFP as representative of the structures founded near or at grade. The dynamic characteristics of the WOFFP manufacturing building in this study are sufficiently similar to those of the process building in the earlier study to base our recommendations on the calculations and evaluation in Ref. 4. For example, the horizontal fundamental frequencles are compared in Table 4 for hard, intermediate, and soft sites.

To cover the possibilley that future manufacturing buildings may be designed with a stibgrade floor level, we also include reconmendations for the "deeply embedied" sategory studies. For this categor, the fuel receiving and storage station at BNFP was selected as represencative.

The recommended models and meciods of analysis given in Table 3 should 
Table 4. Lomparison of fundamental frequencies.

\begin{tabular}{lccc}
\hline Building & $\begin{array}{c}\text { Hard-site } \\
\text { frequencies }(\mathrm{Hz})\end{array}$ & $\begin{array}{c}\text { Intermediate- } \\
\text { site frequencies (tiz) }\end{array}$ & $\begin{array}{c}\text { Soft-site } \\
\text { frequencies (Hz) }\end{array}$ \\
\hline SLanufacturing $^{3}$ & 10.4 & 8.6 & 2.9 \\
Process $^{4}$ & 9.4 & 6.3 & 1.8 \\
\hline
\end{tabular}

bracket all possibilities of future manufacturing building designs.

\section{EQUIPYENT}

The seismic Integrity of equipment can be evaluated by either an equivalent-static method or one of st: eral dynamic methods. Seismic loads can be determined by analyzing either a coupled bullding-equipment systen or by conducting two separate analyses, one on the bullding structure and one on the equipment.

The coupled analysis would require only one set of dynamic response calculations. However, the mathematical model required would be more complex and require many more degrees of freedom in order to Include both the equipment and the support structure. This more complex, larger model is necessary to capture ucourately the response of the equipment. Such a model would not only requ1re muci more computer effort for its soluticn, but would also Increase the $11 k$ : thood of introducIng errors (by $\therefore " ;$ of 111 -conditioned mass and stiffness matrices) in its solution.

Performing separate analyses on the building structure and the equipment is generally more practical. Although two sets of response calculations are required, the models are much more manageable and result in the use of much less manpower and computer time. The building analysis provides the selsulc loading to the equipment. This approach permits the flexiblitty of performing either an equivalent-static or dynamic analysis of the equipment, whichever is most appropriate.

If the mass and/or stiffness properties of the equipment could affect the overall bullding regponse, then a coupled dynamic analysis is necessary. If differential support motion must be considered (for example, because of a long pipeline extending several floor levels), then either a coupled analysis or two separate dynamic analyses with different support motions must be periormea; a static analysis would not be appropriate. 
Seistic input loading for the building analysis is generally in the form of a free-fle]d-groundresponse spectrum or a synthesized accelerogram. Tiris input motion should be compatible with reglonal and local geology and seismicity. The kegulatory position for determining design-basis motion for nuclear power plants is described in Appendty A of Ref. 10. An acceptable ground-motion spectra for rock or soil sites for power plants is described in Regulatory Gulde 1.60. ${ }^{11}$

Seismic Input loading for the equipment analysis is generally in the form of (1) a static coefficient, (2) a floor- or amplifled-response spectrum, or (3) a floor- or amplifiedacceleration record. The static coefficlent is used as a multiplier in the equivalent-static analysis and usually reflects the peak floor acceleration or the peak of the acceleration-response spectrum at the location of the equipment within the bullding. The floor-response spectrum and acceleration timehistories are usially obtained from a dynamic analysis of the support structure and reflect the actual vibratory motion at the equipment support. Approximate methods are also avaflable to develop floor spectra. The avallable methods to determine floor spectra are evaluated in detail later in this report (see jeneration of Ftoo: Spectra).

Seisnic analysis of structures and equipment must consider three componeats of motion: two perpendicular horizontal components and one vertical component. The probabilicy is sma11 that the naximum responses (displacements and stresses) caused by the three directional compouents would occur at the same time and therefore they are usually combined by the square-root-of-the-sur-ofthe-squares (SkSS) nethod.

\section{Definition of Terms}

\section{Single-Degree-of-Freedom System (SDOF)}

The dynamic response of a system subjected to a specifled base motion may be estimated by assuming that its mass, stiffness, and damping properties are concentrated into single ph.'sical eleuents. This model is called a single-degree-of-íreedom system (Fig. 7). Once the system has been modeled the ground- or Floorresponse spectrum can be used directly as input motion to determine the maximum response.

Caution should be exercised in using single-degree-of-freedom representations of systems that phystcally have many possible displaced shapes. A single-degree-of- 


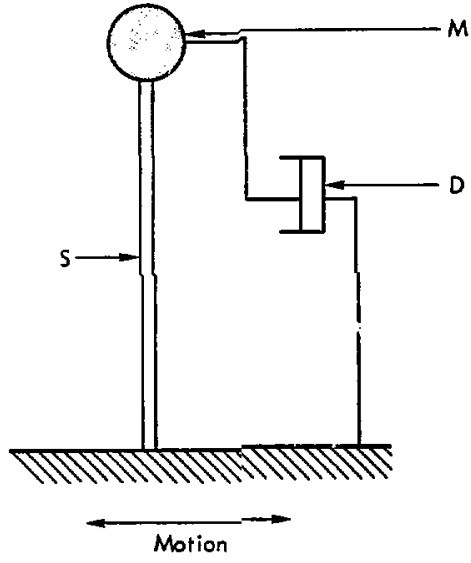

FIg. 7. Single-degree-o $\overline{\mathbf{f}}-\mathrm{f}$ reedom system. Hass concentrated at single point $M$. Damping and stiffuess characteristics concentrated in single elements $\mathbf{D}$ and $\mathbf{S}$, respectively.

\section{Damping Factors}

The response of a structure, system, or component usually has energy dissipation associated with 1 t. These energy losses may be caused by internal energy dissipation within the material or support or joint slippage, and they are normally accounted for by means of a damping value.

Design damping values typically range from 0.5 to $10 \%$ of critical damping. Damping can nave a significant effect on the dynamic response of the structure. Table 5 shows damping values used in the design of power-plant structures. 12 The lower value is for use with operating-basis earthquake motlons, the larger with safe-shutdown earthquake motions.

Iable 5. Damplay values (percent of cricical), ffom kegulatory Guide 1.61 .

\begin{tabular}{|c|c|}
\hline $\begin{array}{l}\text { Structure } \\
\text { or component }\end{array}$ & $\begin{array}{l}\text { Lamping } \\
\text { value }\end{array}$ \\
\hline $\begin{array}{l}\text { Small-diameter ptping } \\
\text { (c } 12 \text { in.) }\end{array}$ & $1-2$ \\
\hline $\begin{array}{l}\text { iquipment eod lacge- } \\
\text { diameter piping } \\
\text { (> } 12 \text { in.) }\end{array}$ & $2-3$ \\
\hline $\begin{array}{l}\text { Steel structures } \\
\text { Weidded } \\
\text { Bolted }\end{array}$ & $\begin{array}{l}2-4 \\
4-7\end{array}$ \\
\hline $\begin{array}{l}\text { Prestressed concrate } \\
\text { structures }\end{array}$ & $4-7$ \\
\hline $\begin{array}{l}\text { keinforced concrete } \\
\text { structures }\end{array}$ & $4-7$ \\
\hline
\end{tabular}


In this study vt:locity-dependent damping was assumed, a standard modeling procedure in structural analysis.

\section{Response Spectrum}

A response spectrum is represenced schematically in Fig. 8. A series of

(a)

Base
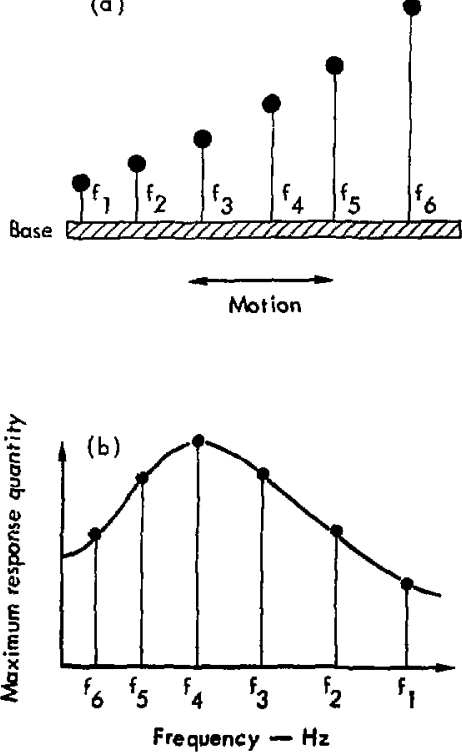

Fig. 8. Simulated cantilevered beams of varying reaponse frequenctes, (a) Pendulums of vary ing response frequency. (b) Plot of maximum response quantity for each alngledegree-of-freedol aystem for particular input motion. single-degree-of-freedon systems (cantilever pendulums) with varying fundamencal frequencies are fixed =0 a moveable base. As the length of the pendulums increases, the fundainental frequency decreases. If the base is moved with a time-varying motion and the motion of each pendulum is recorded, a curve can be developed that plots the maximum response against the frequency of each pendulum. This curve is called the response spectrum for that particular input motion, and is also snown in Fig. 8. The respanse motion can be aisplacement, velocity, or acceleration, beciuse all are related to frequency. It is possible to generate spectra for both vertical and horizontal base motions.

\section{Ground-Response Spectrum (Free-Field)}

If the serieg of sinyle-degreeof-freedom systems (pendulums) are assuned supported on tne ground and are subjected to free-field ground motion resulfing fron an eartnquake, then the response-spectrum curve developed is called a ground-notion spectrum. Figure $9 a$ shows an example of the acceleration ground-motion opectrum for the 1940 El Centro earthquake. Figure $9 \mathrm{~b}$ shows the measured torizontal accelerogram record used as input to develop this spectrum. 

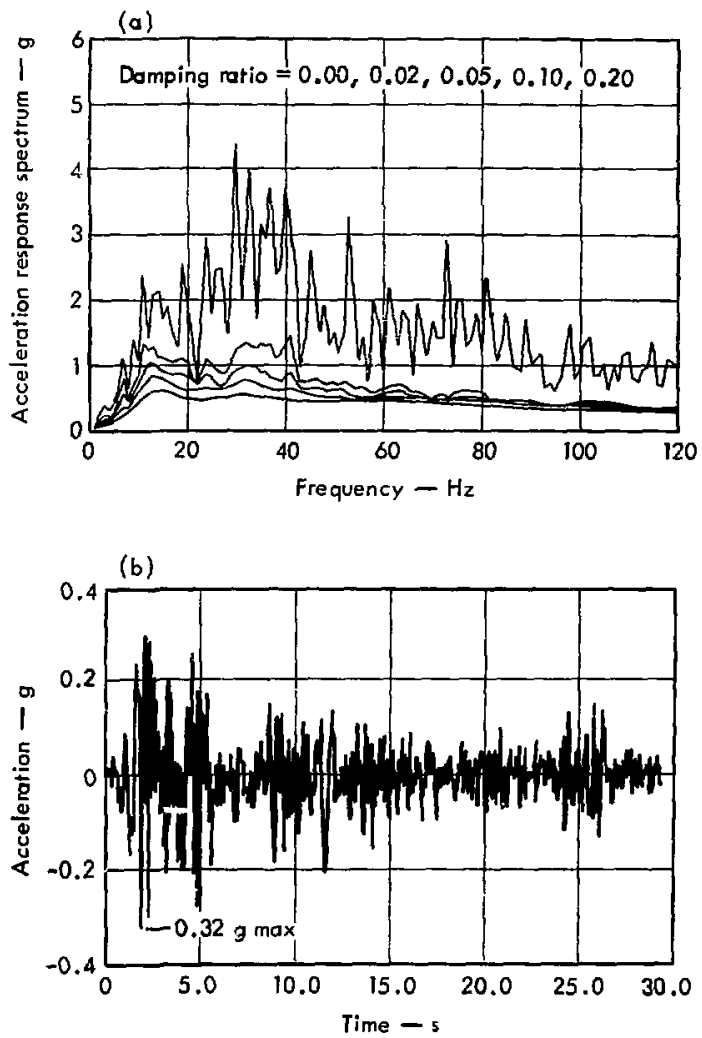

F18. 9. 1940 E1 Centro earthquake. (a) Acceleration response ouectrum. (b) Accelerogram. 
Figure 10 shows the tree-fieldground-rrotion spectrum currently used to defing seismic input for nucl.ear power reactors. 11 This smooth spectrum is based on a statistical treatment of approximately 47 earthọake records and is plotted on tripartite lug paper for the convenience of having maximum acceleracion, veloctcy, and displacement values as a function of frequency on one plot. Both hortzontal and vertical spectra are given for different values of damping. Both ate normalized to a maximum horizoncal ground acceleration of $1.0 \mathrm{~g}$. Once the incensicy of ground motion for a site is specified in cerms of maximum horizontal ground acceleration, both horizontal and vertical spectra can be defined simply by scaling.

\section{Floor- or Amplifled-Response Spectrum}

Fjoor-response spectra are similar to ground-response spectra except that the base of the serles of cantllever beams is located at a particular floor level in the buildIng rather than on the ground. Unless the building is rigid (that 1s, hus a frequency greater than $33 \mathrm{~Hz}$ ) the response motion at different elevations in the bullding will be different than the base ground motton. listally the motion 18 amplified, resulting in a floor spectrum with larger response values than groundmotion-spectrum values for a given frequeacy. Several nethods avallable to generate floor spectra are discussed in tile siccion Seneration of Floor Spectra.

\section{Rigid and Flexible System}

In general, rigid systems are defined as those with fundamental frequencles in excess of $33 \mathrm{kiz}$. This is consistent with Regulatory's position for power reactors. In Fig. 10, for example, there is no anplification over tne $1-g$ ground motion for frequencies greater than $33 \mathrm{kz}$. Rigic systems exibit no response amplification above the support or bas motion. Tne response spectrum developed for a base motion from the 1940 El Centro eartinquake (Fig. 9) shows the spectral acceleration equal to the peak ground acceleration for frequencies greater than $20 \mathrm{hz}$.

Flexibla systens are defined as those with fundamental frequencies less than $33 \mathrm{~Hz}$.

Stat d.c Analysis

Sratic analysis reiers to the application of static horizoncal or vertical design load to a structural system. Thece loads are usually expreased as a coefficient or 


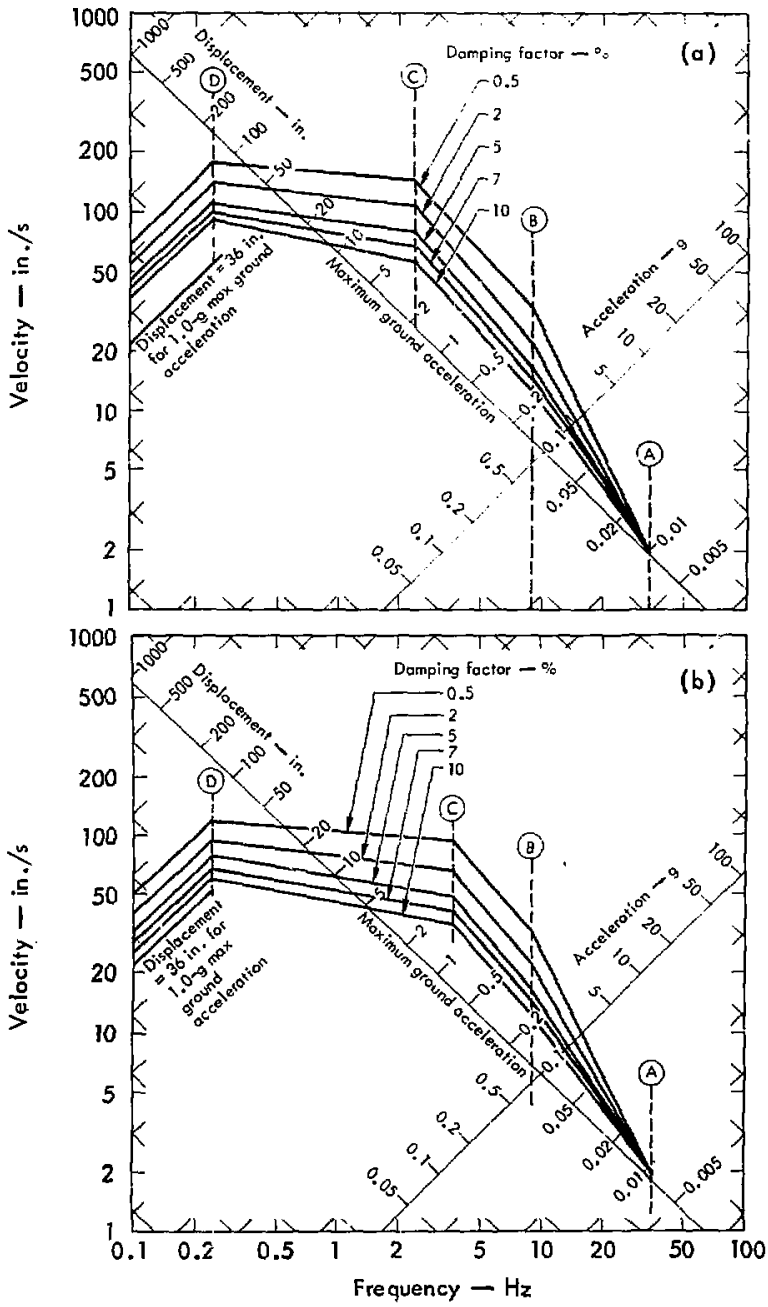

Fig. 10. Design response spectra, scaled to $1-g$ horizontal ground Bcceleration (from Regulatory Guide 1.60). (a) Horizontal. (b) Vertical. Example: for $5 \%$ damping and $f=0.25 \mathrm{cps}$, $\mathrm{D}=73.8 \mathrm{in}, \mathrm{v}=115.93 \mathrm{in} . / \mathrm{s}, \mathrm{a}=0.47 \mathrm{~g}$. 
multiplier of the acceleration of gravity. The loads are ilstributed consistent with the mass or weight distribution of the system.

Generally, the coefficient is based on the seismicity and soll characteristics at the site as well as the dynamic response characterIstics, type, and function of the structural system under analysis. Another conmon way to determine the coefficient is to use the response spectrum defined for the structural system's base motion and an assumed damping value. Often the peak of the acceleration spectrum is chosen to develop an equivalent static load to apply at the center of gravity of the system. This, in effect, assumes thi: the structure behaves as a single-degree-of-freedom system in resonance with the support or base mocion. No natural-frequency calculation is performed on the structural system.

\section{Dynamic Analysis}

In dynamic analysis the dynamic properties of the system (frequencies and mode shapes) are used to develop the seismlc loads for design. One of two methods is used: the responsespectrum method or the time-history method.

The response-spectrum method requires the base motion to be in the form of a response spectrum. ilode shapes and frequencies of the mathematical model must be calculated. Because of the way the modal quantities are combined to get the total response, this method yields only an approximation. The response is calculated (such as for displacewent or loads) in each prode, and all the calculated responses are superposed by the sRSS procedure. This procedure is used because the maximum value in each mode may not occur at the same time. The procedure is madifiad when closely spaced modes occur. Enough twodes must be included in the analysi., capture the complete struccural response.

The time-history method determines the structur 1 response to an arbitrary force-time history or acceleration-time history. The method solves the equations of motion teveloped for the systen at each $t$.me step using one of two approaches: mode superposition or direct integration.

Using mode superposition the eigenvalue problem associated with the model is solved to determine the mode shapes and frequencies of vibration. The response of each mode Is then determined and all modes are combined to get the total response. This approach is limited to the linear response of structures. 
The direct integration approach is used to obtain a solution by stepby-step integration of the equations of motfon. Solution of the efgenvalue problem is nct required, and nonlinear effects may be included if required.

Either approach gives an "exact" time-history of response. A direct integration analysis is equivalent to an analysis by the mode-superposition approach in which all mode shapes and frequencies are included and the same time step, $\Delta t$, is used. Both approaches Involve larger amouits of computer time than the responsespectrum method to solve for the dynamic response of a structure because small time steps are required to achieve meaningful results.

For more detailed discusston of the stafic and dynamic methods, particularly the advantages and disadvantages of each, see Ref. 4.

Available Methods

We have categorized the different seismic analysis methods for equipment according to the dynamic response characteristics of both the building (or support structure) and the equipment. The response characteristics of the building will Influence the choice of selsmic loading suitable for equipment analysis. The response characteristics of the equipment will dictate the suitable method of analysis.

Figure 11 illustrates the standard * approach used to develop seismic loading to equipment located at different levels in the building. The Input seismic loading to the building is usually expressed in the form of an accelerogram considered representative of the free-field ground motion at the site $\left(A_{G}\right)$. The free-field accelerogram is usually (1) based on a single recorded earthquake accelerogram considered representative of the site or (2) developed from a free-field response spectrum $\left(S_{G}\right)$ based on a statistical treatment of many past earthquake records.

When an acceleration timehistory is required, a syntheslzed accelerogram $\left(A_{G}\right)$ is derived from the free-field response spectrum. An example of this approach is Regulatory Guide 1.60, which defines the seismic Input for nuclear power reactors.

The free-field ground motion $\left(S_{G}\right.$ or $A_{G}$ ) is used as the exciting motion to a lumped-mass or finite-element model of the building. This model usually includes soll springs, which permit soil-structure interaction effects to be considered.

\footnotetext{
Approximate approaches are discussed in the section Generation of Floor Spectra.
} 
The dynamlc response of the model is calculated using a computer program. Response quantities incluro member forces, displacements, velocities, and accelerations throughout the bullding. Figure 11

1llustrates calculated acceleration time-histories at different floor

levels $\left(A_{F}\right)$. Depending on the location of the equipment, the accelerograms can be used directly as Input to an equipment dynamic analysis. An alternative technique is to develop acceleration-response spectra

corresponding to these floor accelerograms, designated as $S_{F}$ in Fig. 11 . These floor spectra are then used as input to the dynamic analysis of equipment.

An equivalent-static analysis of equipment uses a single value from either the acceleration time-history or acceleration-response spectrum to reprefent the selsmic force. These Include, for example, maximum grouna or floor acceleration ( $A_{G}^{\max }$ or $A_{F}^{\text {max }}$ ) and ground- or floor-spectra values that correspond to the frequency of the bullding or equipment $\left(S_{G}, S_{G}\right.$, $\mathrm{S}_{\mathrm{F}}$ ). Appropriate damping values must be used.

Figure 12 Identifles 11 methods for evaluating the seismic integrity or equipment. To find the approprlate method we first determine the stiffness of the building that houses the equipment. We then determine the stiffness of the equiprent. Finally, after these two stiffnesses are known, the prectsion in the seismic Input load Indicates the appropriate analysis method.

The two classes of stiffness, in either buildings or equipment, are rigid and flexible. Rigid systems are those that exhibit no response amplification when subjected to input motion. Flextble systems exhlbit response amplification. For example, for the design of power plants Regulatory Gulde 1.60 suggests $33 \mathrm{~Hz}$ as the frequency cutoff for rigid structures. Those structures wth fundamental frequencles greater than $33 \mathrm{~Hz}$ need not be designed for amplified acceleration levels. Flexible structures include those with frequencies less than $33 \mathrm{kz}$. For our purposes the 33-Hz value appears reasonable as the dividing line between rigld and flexible buildings and equipment.

As shown in Fig. 12, methods 1 through 4 pertain to the rigidbutlding situation and rathods 5 through 11 the flexible-butlding situation. Because no dynamic response characteristics or calculations are required for rigld buildings, methods 1 through 4 can determine selsmic equipment Icading directly from the free-fleld ground wotion. 

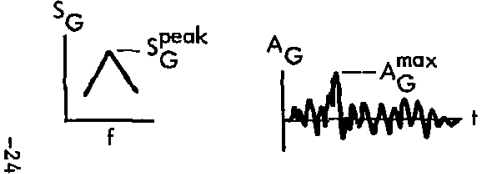

Earthquake motion

Free-field accelerotion time-history is developed from frese-field ground motion spectrum (i.e. synthetic accelerogram). zontal) usually fvertical or horidefined as acceleration spectrum.

Input motion
Free-field seismic
ground motions
(vertical or hori-
zontal) usually
defined as accel-
eration spectrum.
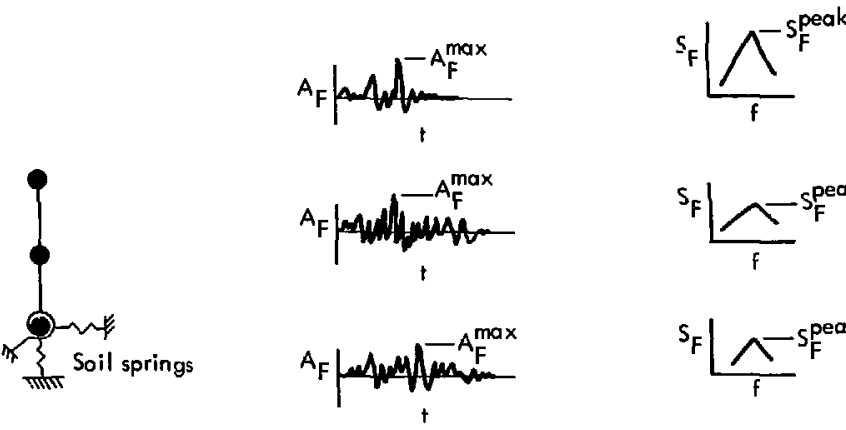
Model
Model (LM or FE) of
building structure that includes foundation effects (via soil springs).
Response
Acceleration time-history response of the model is calculated at different building levels by using dynamic analys is techniques.

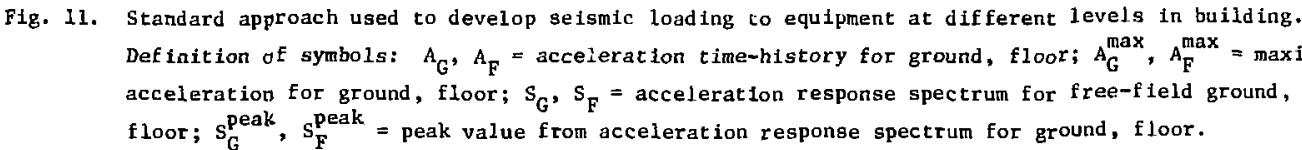

Fig. 11. Standard approach used to develop seismic loading to equipment at dif ferent levels in building,
Definition of symbols: $A_{G}, A_{F}=$ acceleration time-history for ground, floor; $A_{G}^{\max }$, $A_{F}^{\max }=\operatorname{maximum}$
acceleration for ground, floor; $S_{G}, S_{F}=$ acceleration response spectrum for free-f leld ground,
floor; $s_{G}^{\text {peak }}, S_{F}^{\text {peak }}=$ peak value from acceleration response spectrum for ground, floor.

Fig. 11. Standard approach used to develop seismic loading to equipment at different levels in building
Definition of symbols: $A_{G}, A_{F}=$ acceleration time-history for ground, floor; $A_{G}$, $A_{F}^{m a x}=m a x$
acceleration for ground, floor; $S_{G}, S_{F}=$ acceleration response spectrum for free-f leld ground,
floor; $S_{G}^{\text {peak }}, S_{F}^{\text {peak }}=$ peak value from acceleration response spectrum for ground, floor.

Fig. 11. Standard approach used to develop seismic loading to equipment at dif ferent levels in building
Definition of symbols: $A_{G}, A_{F}=$ acceleration time-history for ground, floor; $A_{G}^{\text {max }}, A_{F}^{m a x}=m a x$
acceleration for ground, floor; $S_{G}, S_{F}=$ acceleration response spectrum for free-f leld ground,
floor; $S_{G}^{\text {peak }}, S_{F}^{\text {peak }}=$ peak value from acceleration response spectrum for ground, floor.

\section{Floor spectro \\ Floor or amplified acceleration response spectra are generated from calculated acceleration time- history results of each level.}




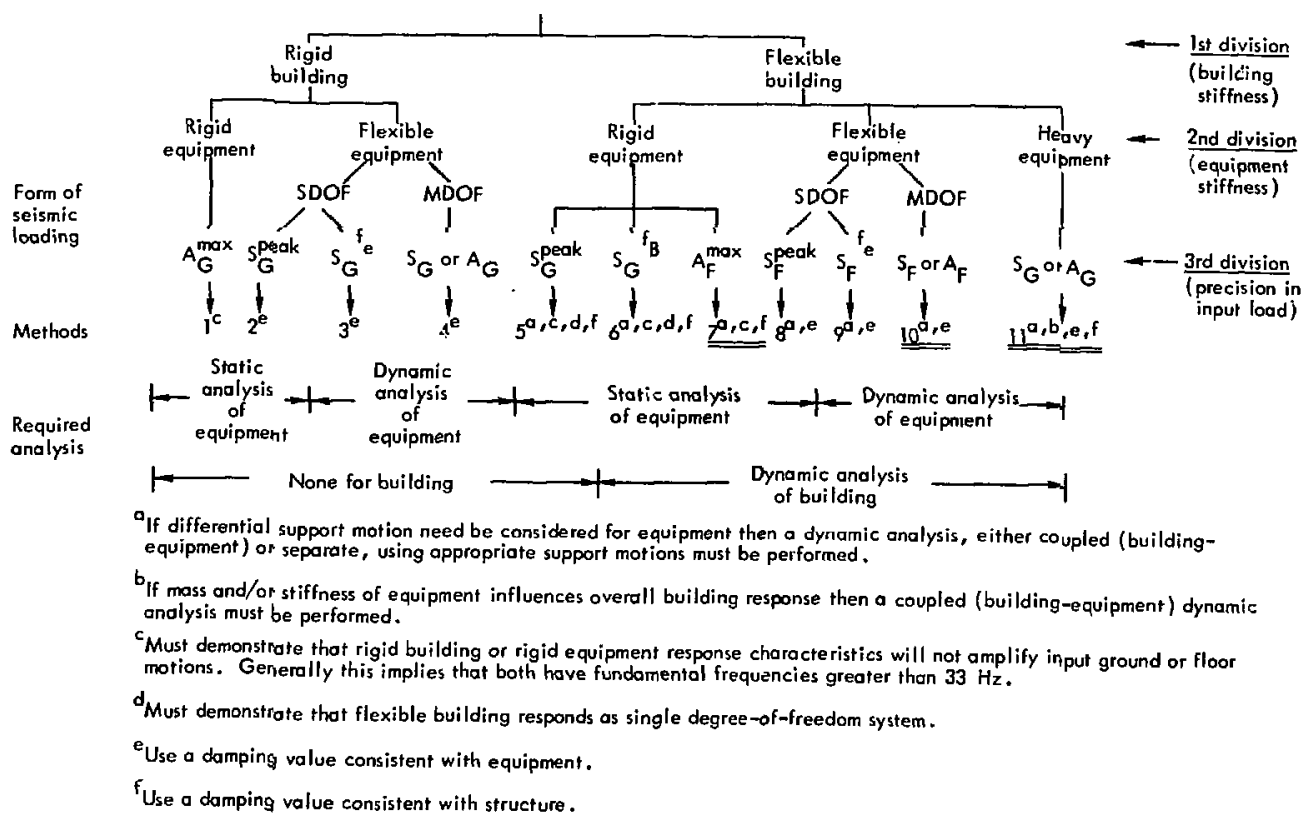

Fig. 12. Decision tree showing analysis method to evaiuate seismic integrity of equipment. Double underscores indicate recommended methods. Definltion of symbols: $A_{G}, A_{F}=$ acceleration time-history for ground, floor; $A_{G}^{\max }, A_{F}^{\max }=\operatorname{maximum}$ acceleration for ground, floor; $S_{G}, S_{F}=$ acceleration response spectrum for free-field ground, floor; $s_{G}^{\text {peak }}, s_{F}^{\text {peak }}=$ value from acceleration response spectrum for ground, floor; $s_{G}, s_{G}, s_{F}=$ acceleration response spectrum value corresponding to frequency of building, equipment for ground, floor. 
Hechod I (rigid bullding, rigid equipment) recognizes that no load amplificacion over the free-field values is posolble and therefore uses the maximum ground acceleration $\left(A_{G}^{\max }\right.$ ) as the static coefelctent or multiplier for an equivalent-static equipmenc analysis.

Nethod 2 (rigid bullding, flexible zquipment) accounts for the situation where the maximum seisinic equipment loading must include amplification of the maximum ground-motion acceleracion. It conservatively selects the peak-ground-moticn-spectrum value $\left(S_{G}^{\text {peak, }}\right.$ ) using a damping value consistent with the equipment. The equipment must respond as a singledegree-of-freedom system.

Method 3 (rigid building, flexible equipment) accounts for the same situation as method 2 , but with the conservatism removed. Nethod 3 selects a ground-motion-spectrum value consistent with both the fundamental frequency and dampling of the equipment. It also requires the additional effort of calculating the fundamental frequency. The equipmenr. here, too, must respond as a singledegree-of-freedom aystem.

Nethod 4 (rigid building, Elexible equipment) is used when the equipment does not respond as a single-degreeof-freedom system. Here, either the free-field groun: accelerogram $\left(A_{G}\right)$ or response spectrun $\left(S_{G}\right)$ are used as input to a dynamic equipment analysis. Elther response-spectrum or cimehiscory methods of analysis are appropriate.

Hethoi 5 (flexible bullding. rigid equipment) is a special case. Although it falls into the flexiblebuilding class, because the equipment is considered rigid the selsmic forces can, as in methods 1 chrough 4 , be related directly to the freefleld ground motion. As long as the building responds primar!ly as a single-degree-ot-freedom systen the maximum possible seismic loading to che equipmenc can be expressed as a function of the peak-ground-responsespectrum value.

Methods 6 chrougin 11 are in the flexible-building class and therefore require dynamic characteriscles and/ or response calculations of the buildIng to decermine the inpur seismic loading to the equipment.

sethod 6 (flexible building, rigid equipment) uses the free-field ground motton directly. Here, as in method 5 , the bullding must respond $B$ a single-degree-of-freedom system. Because the equipment is considered rigid, no dynamic response calculatlons are required. however, the fundamental frequency and damping of the buildigg must be determined so that a spectral acceleration value 
correspondiag to the bullding (requency $\left(s_{0}^{i v}\right)$ ean be obealned. This correspunding acceleralion value often results in a subscant lal load reduct lon uver feciod 3 .

ilechou i (ilexlole bullulas. rlgld equipment) do for rlyidequipeutit sases where tito bullding does not respond as a mlagle-degreeof-riectom systes. It usus time maxlenue flooz acculeration $\left(A_{F}^{\max }\right.$ ) as tho statc coefficient. To yer this haxleurn floor aceeleraclon a dynamlc Jesponoc analysto ds Equatrad of the buildiag usins a eulclple-degrue-oftreedom model. Ficher a modal analysis or tine direct netiod of soiuction can bu used.

Hecliod \& (f)exible butlding, flexible equipment) uses elcher the flaor response spectrum $\left(S_{F}\right)$ or floor ucceleracion $\left(A_{F}\right)$ for the sedsmie sotion. Here, the equipment must respond as a single-degree-of-treedow system, and the peak apectral value $\left(s_{F}^{\text {peak }}\right)$ is conservatively selected as the static coefilcient.

Jechod 9 (flextble bullding, flexible equipment) is the same as method 8 except that the spectral value selected $\left(5_{F} f_{e}\right.$ ) is lese conservative and consistent with the calculaced fundamental equipment frequency.

Mechod 10 (flexible bullding. flexible equipment) also uses either the iloor-response spectrum $\left(S_{E}\right)$ or tloor acceleracion $\left(A_{F}\right)$ for the seistic motion. Hut here the equipment can be $a$ mulelple-degree-offrector sistum. Elther responseepectrum or cime-hiscory methodn if solucion san be used.

:lechod 11 (flexible bullding, havy (equiptenc) is cho speclal case wher the equipent is of sufficient mags and/or setedacsis to itfect che overall dynabic rasponse of the bullding. liere, dynaric responee calculacions nust be made on a coupled bullding-equipsent sodel. Free-field ground fotion $\left(S_{G}\right.$ or $A_{C}$ ) can be used for analyels. Licher response-spectrum or cIne-inlstory metiods of solucion are appropriate.

Several general comencs can ba made reyarding che seleccion process described in FIs. 12.

1. I $i$ a frequency value of approximacely $33 \mathrm{hz}$ is used to delineate becween rigid and flexible syscems, very few building structures used at nuclear factilieses (particularly if sofl-structure Interaction effects ars. important) will fall into the rigid class. As scated earlier, the 33-hz value is conglacent with degulatory Cufde 1.60 for ptwer plant buxldings. 
2. When cnoosing between methods 2 and 3, methods 5 and 6 , and fletinuds 0 and 9 for liost bulldings and equipnent comblnations, cue latter method in each pait will be the most practical because of the undestrable conservarism associated with using the peah-response-spectrun value. Tne a:ditional effort required to determine the fundamental frequency will be justifled.

3. Winen choosing between methods 2,3 , and $4 ;$ mechods 5,6 , and 7 ; and methods 9 and 10 because of tne single-degreeof-freedom requirement, it will generally be more practical to use mechods 4 , 7 , and 10. Nost of the equipment and bulldings are sufficlently complex that they cannot be modeled as a slar:e-degree-of-freedom system. Further, once the response characteristics ri:- assary to determine whether or not the system responds as a single-degree-of-freedom system are calculated, very litcle addictonal effort is required for the dynamic response solution.

4. Given only a single piece of equipment to evaluate in a building, the methods most frequently applied will be methods $1,4,7$, or 10 . The usual situation is to calculate the response of many pieces of equipment located in one building. Nethod 10 is probably the best compiomise since floor spectra only need to be computed once.

5. If differential support motion need be considered for the equipment (e.g., a plpe chat extends over several floor levels), then a dynamic analysis is required. The single analysis using a coupled building-equipment model may be performed, or two geparate analyses using appropriate support motion may be conducted.

\section{Comparison of Methods}

The dynamic response characteristics of the manufacturing building we consider representative of future fuel fabrication buildings is discussed in detail in the section Generation oj Floor Spectra. The basls for the bullding design is discussed in the section Critical Structures and Equipment.

The fundamental frequencles of the bullding were calculated for two site condticns for both horizontal 
and vertical ground motlons. The first site reflects an average site shear velocity of $3500 \mathrm{ft} / \mathrm{s}$, and the second, a softer site, reflects a shear velocity of $1500 \mathrm{ft} / \mathrm{s}$. The calculational model included soil springs to account for soil-structure Interaction effects. The calculated fundamental frequencies for horizontal motion were 7.7 and $9.7 \mathrm{hiz}$ for the soft and hard sites, respectively. The calculated frequency for vertical motion is $7.7 \mathrm{hz}$ for both site characterizations.

Using the 33-Hz frequency value for the diviston between rigid and flexible structure classes, the manufacturing building must be considered a flexible structural system. The fundamental frequency of building hortzontal motion is dominated by the end shear walls; for vertical motion the floor and roof slabs dominate the response characterIstics. Even with substantial variations in wall and slab design (e.g., decrease or increase of thickness by as much as 50\%) the building would still fall within the flexible rather than rigid class.

Figures 13 and 14 show the acceleration floor spectra calculated for different levels of the manufacturing bullding for both horizontal and vertical motlons. The floor spectra are for $0.5 \%$ damping. Also biven are 0.5 and $4 \%$ free-tieldground-motion spectra. These spectra were developed irom tht syntinesized free-field accelerogram that was used tor the time-history response analysis of the building model. The $4 Z$ spectrum is consistent with that used for the bullding response analysis. The $0.5 \%$ spectra are included to permit a comparison of free-field motion with calculated building response motion for the same damping. The free-field ground motion reflects a $1-g$ maximum ground motion for both horizontal and vertical directions. For other maximum horfiontal free-field motion the floor- and groundresponse spectra can simply be scaled.

These figures clearly show butlding influence on the selsinfc loads to equipment. The response characteristics of the butlding clearly amplify the ground motion. For example, Fig. 13 (horizontal motions, soft site) shows roof, second-floor, and ground-floor peak spectral values of 114,80 , and $45 \mathrm{~g}$, respectively: for $0.5 \%$ damping. The effect of the bullding furdamental frequency can also be observed to force the largest amplification near that frequency. The ground-motion spectrula shows a lesser peak amplificstion of 10 to $12 \&$ at $0.5 \%$ over the $I-g$ maximum horizontal ground 


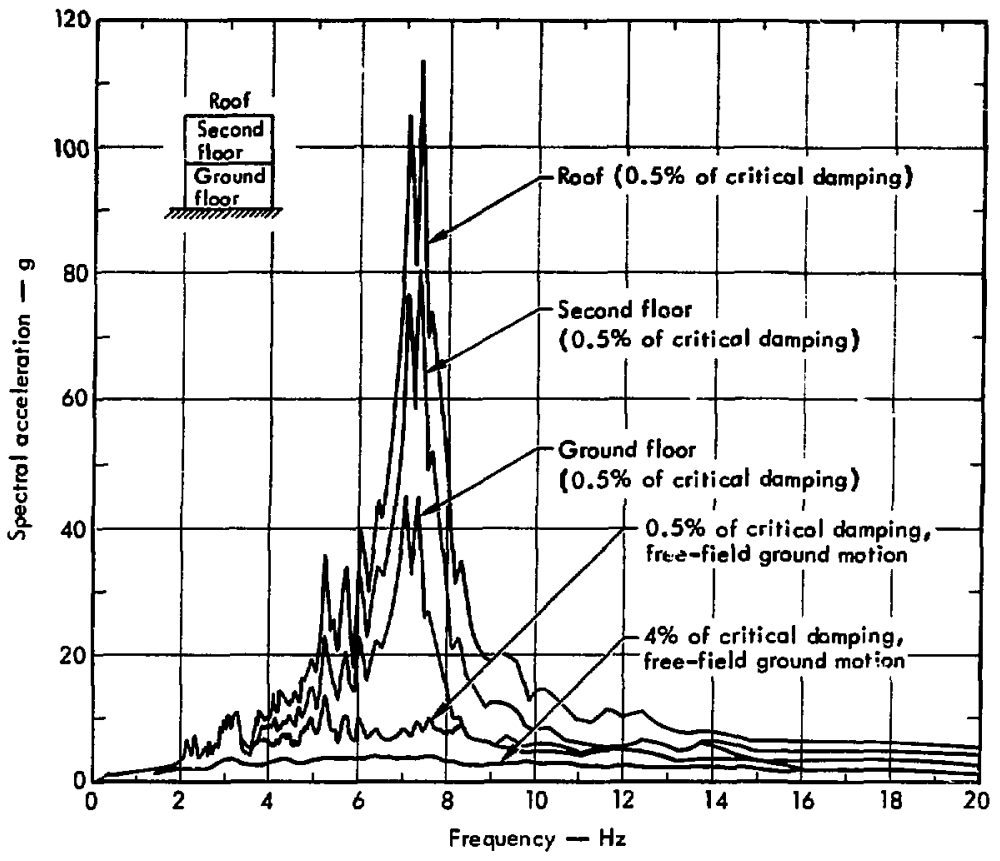

F1g. 13. Free-fleld ground motion and calculated floor response spectra, horlzontal motions, soft site. 


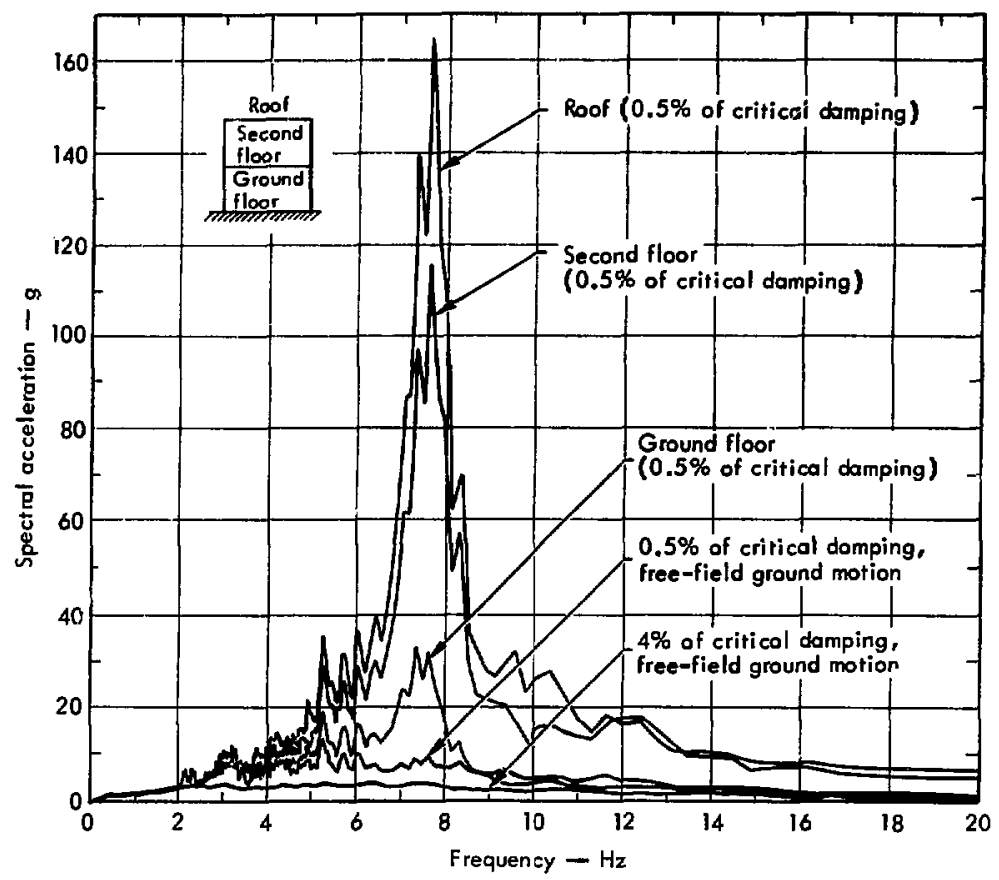

Fig. 14. Free-fleld ground motion and calculated floor response spectra, vertical motions, soft site. 
acceleration but over a wider frequency range. Similar amplifications are shown in $\mathrm{F} I \mathrm{~g}$. 14 .

Soll-scructure interaction effects influence cile seisnit: luading co che equipment. Figure il sibuws a freefleld-spectra amplificat loj factor of approximacely $4(45 / 12)$ over the ground floor at a trequency near the building iundamental frequency. This amplification is directly attributed to the soil springs.

Table 6 shows estimated fundamental frequencles of each of the critfical pieces of equipment. Variatlons in equipment design could substantially nodify these frequency estimates. For example, the docation of support points plays a significant role in the response characteristics of the equipment. For this reason and also because future equipmenc destgns may be substantially different we have decided not to use the estimated equipment frequencles when comparing seismlc equipment loads. Instead, we w1ll assume that the criclcal equipment could have any fundamental Erequency less than $20 \mathrm{kz}$.

A comparison of selsmic equipment loads determined using the different methods discussed previously is giver In jahle 7. The acceleration values shov aflect horizuntal building motion for a soft site (FIg. 13). The input free-field ground notion is based on a 1-8 maximum horizoncal ground motion.

Tiable 6. Estimated f undamencal frequency of critical equipment.

\begin{tabular}{|c|c|}
\hline Critical equipment & $\begin{array}{c}\text { Estifuaced } \\
\text { irequency } \\
\text { (Hz) }\end{array}$ \\
\hline $\begin{array}{l}\text { linloading station } \\
\text { (gloved box) }\end{array}$ & $14-20$ \\
\hline Buik storage & $25-50$ \\
\hline Mixed-oxide storage & $25-50$ \\
\hline $\begin{array}{l}\text { Transfer system } \\
\text { (piplng) }\end{array}$ & $j-20$ \\
\hline $\begin{array}{l}\text { Scrap recovery systent } \\
\text { (gloved box) }\end{array}$ & $10-20$ \\
\hline $\begin{array}{l}\text { Veatilation sygtem } \\
\text { (ducting) }\end{array}$ & $5-20$ \\
\hline Final hEPA Érape & $5-10$ \\
\hline
\end{tabular}

Table 7. Comparison of selsmic equipmenta loads determined using different methods, horizontal motion, soft site.

\begin{tabular}{|c|c|c|}
\hline Hethod & $\begin{array}{c}\text { Equipment } \\
\text { Erequency } \\
\text { (Hz) }\end{array}$ & $\begin{array}{c}\text { Accelerat } \operatorname{Lon}^{b} \\
\text { (g) }\end{array}$ \\
\hline 1 & $3:$ & 1 \\
\hline 2 & $3-8$ & 12 \\
\hline 3 & $0.25-33$ & $1-12$ \\
\hline 5 & $3-8$ & 4 \\
\hline 6 & 7.7 & 4 \\
\hline 7 & 33 & 4 \\
\hline 8 & 7.7 & 80 \\
\hline 9 & $0.25-33$ & $4-30$ \\
\hline
\end{tabular}

${ }^{a}$ Equipment assumed to be located on second floor of manufacturing bullding.

${ }^{\mathrm{b}}$ See F1g. 13. 
The equipment is assumed co be located on the second fioor of the manufacturing bullding. The tuildInf is assumed to have $4 \%$ damping and the equipment $0.5 \%$ damping. As previously indicated, we assume that future manufacturing bufldtugs will fall wichin the flexible-building class (methods 5 so 11). However, for comparison we include seismic equipment loads that reflect the rigid-butlding class (methods 1 to 4). Nethods 4, 10, and 11 are not included in the comparison because it would be necessary to completely define the equipment destgn.

To facilitate comparison, we can brlefly describe the methods listed In Table 7 as follows:

Mechod 1 (rigid bullding, rigid equipment), Because the freefleld ground motion is not amplified, che maximum selsmic loading on the squipment is the maximum ground acceleration, 1 g.

\section{Method 2 (rigid bullding, flextble}

equipment). This method selects the peak free-field spectral acceleration for the selsulc equipment loading. kather than requiring a frequency calculation for the equipment, it conservatively uses the peak free-field spectral value of $12 \mathrm{~g}$ that assumes the equiprent frequency to colncide with the dominant iree-field frequency on the $0.5 \%$ damping curve.

Method 3 (rigid bullding, flexible equipment). This mechod assumes that the equipment frequency is determined and chat the result is a seisraic equipment loading that ranges from 1 to $12 \mathrm{~g}$, depending on the actual equipment frequency.

Method 5 (flexible bullding, rigid equipment). Because the rigid equipment will not further amplify the free-field motion above that of the flexible building, this method uses the peak-ground motion-spectrum value of $4 \mathrm{~g}$ ( $4 \%$ bullding damping). It does not require a frequency calculation; It assumes that the bililing fundamental irequency matches the dominate frequency of the freefield motion. It also assumes that the bullding responds as a single-degree-of-freedom system.

Method 6 (flexible building, rigid equipment). Thts method uses the calculated frequency of the bullding ( $7.7 \mathrm{~Hz})$, which results in a corresponding ground-motion spectrum value of $4 \mathrm{~g}$. It assumes that the butlding responds as a single-degree-of-freedom system. 
Method 7 (flexible building, rigid equipment). This method assumes the bullding has multiple-degreeof-freedom characteristics and ylelds a seismlc equipment load of 4 \&. This value is based on the maximum second-floor acceleration, which is the same as the second-floor spectral acceleration corresponding to a frequency of $33 \mathrm{~Hz}$ or gieater at $0.5 \%$ damping. sethod 8 (flextble bullding, flextble equipment). This method requires a floor-response spectrum, the result of a dynamic building analysis approprlately accourting for the flexibllity of the buildIng, as the Input selsmic motion to the equipment analysis. It selects the peak spectral floor acceleration of $80 \mathrm{~g}$ (0.5\% damping) to arrive at the selsmic load for the equipment. It w111 produce extremely conservative loads unless the equipment fundamental frequency matches very closely that corresponding to the peak floor spectrum. It assumes that the equipment responds as a single-degree-ofErezdom system.

Method 9 (flextble building, flexible equipment). This method requites a floor-response spectrum as the 1r.put seismic motion to the equipment analysis. It also requires the determination of the fundamental frequency of the equipment, resulting in equipment loads that could vary from 4 to $80 \mathrm{~g}$ depending on the actual equipment frequency.

Future fuel fabrication manufacturing buildings and most critical equipment will fall into the flexible bullding, flexible equipment class of methods 8 and 9.

\section{Conclustons}

The conclusions that follow are based on the dynamic response characteristics of fucure marufacturIng bulldings and the pros and cons of the different methods of analysis.

Future fuel fabrication manufacturing bulldings should be considered flexible structures. Therefore, we are concerned only with methods 5 through 11. These choices provide for the possibllities of rigid, flexible, or heavy (rigld or flexible) equipment.

For rigid equipment we recommend method 7 over methods 5 and 6 . Methods 5 and 6 require that the manufacturing bullding respond as a single-degree-of-freedom system. The dynamic analysis we performed (in the section Generation of Floor Spectra) clearly demonstrates that 
the butlding nust be modeled as a mult 1ple-degree-of-freedom system.

For flexible equipment we recommend method 10 over methods 8 and 9. In most cases method 8 will yleld loads that are too conservative. Method 9 not only requires that the fundamental frequency be calculated, but also that the equipment responds as a single-degree-of-freedom system. With the exception of the simpler equipment configurations, most equipment will require a multipledegree-of-freedin analysis. Furthermore, the additional analysis effort for the frequency determination in method 10 is small beyond that already required by method 9 .

For heavy equipment, which could affect the overall response of the building, method 11 is necessary.

These recommendations are summarfzed in Table 8.

Table 8. Recommended methods for seismif analysis of equipnent located in flexible buildings.

\begin{tabular}{lll}
\hline $\begin{array}{l}\text { Equipment } \\
\text { stiffiness }\end{array}$ & $\begin{array}{c}\text { Recommended } \\
\text { method }\end{array}$ & \multicolumn{1}{c}{ Descriftion } \\
\hline $\begin{array}{l}\text { Rigid } \\
\text { equipment }\end{array}$ & Nethod 7 & $\begin{array}{l}\text { Use maximum floor acceleration and conduct } \\
\text { static analysis of equipment }\end{array}$ \\
$\begin{array}{l}\text { Flextble } \\
\text { equipment }\end{array}$ & Method 10 & $\begin{array}{l}\text { Use floor-response spectra or floor- } \\
\text { acceleration time-history and conduct } \\
\text { dynamic analysis of equipment }\end{array}$ \\
$\begin{array}{l}\text { Exceptionally } \\
\text { heavy } \\
\text { equipment }\end{array}$ & Method 11 & $\begin{array}{l}\text { Use ground-response spectra or ground- } \\
\text { acceleration time-history and conduct } \\
\text { coupled dynamic analysis of butiding- } \\
\text { equipnent system }\end{array}$ \\
\hline
\end{tabular}




\section{Generation of Floor Spectrs}

Almost all seismic analyses of equipment 1nvolve tre use of floorresponse spectra. In most instances a complete set of response spectra are calculated for the building prior to equipment desiga. The floor spectra will encompass motion in three orthogonal directions at aj 1 possible equipment locations and damping.

The tine-history method is normally used to calculate the floorresponse spectra. This can be accomplished by enveloping tine floor spectra generated from the response of the structure to several recorded earthquake ground motions. The approach currently favored by degigners is to use a synthesized ground mation whose spectrum envelopes the probable site spectrum at all frequensies of interest.

Additionally, approxtmate methods have become avallable for generating floor spectra, Although developed by different autnors, these methods share certain characteristics: the response spectra of the ground motion and a modal dialysis of the building are required as input; no tine-history calculations are required; the methods are tenerally more conservative than the time-history approach.
There are trree main reasons for using one of the approximate metnods in lieu of the time-history approach:

1. A synthetic accelerogram need not be generaced

2. An approximate method is less complex

3. Less analyst and computer time is required.

Two approximate methods were developed by Kapur ${ }^{13}$ and Biggs. 14,15 Kapur's method was published in 1973. Biggs" method was first published in 1970 and In 1971 revised to be more conservative.

We assessed the suitabllity of the Kapur and BIggs methods for use on MOFFP's. (We used the more recent method presented by Blggs in Ref. 14.) Both authors have demonstrated the conservatism that results wher their methods are used on power reactor bulldings. Because MOFFP bulldings have different response characteristics (such as higher natural frequencies) than power reactors, we felt it appropriate to re-examine the lssue.

To accomplish this, we developed a free-field synthetic accelerogram whose response spectrum envelopes those of many past earthquakes. Four 
structural models of our MOFFP

building were developed that encompass the range of dynamic characteristics expected in the future. The four consist of vertical and horizontal response models founded on soft and nard soil. Floor-response spectra were generated witn tne tine-history, Kapur, and Biggs metrods for all four models and tne resulcs compared.

\section{FLOOR-SPECTKA CALCULATIONS}

\section{Ground Motion Lsed}

As noted previously, the timehistory thethod for calculating floor spectra requires a free-field-groundmotion accelerogram. The approximate methods require response spectra of the ground motion. We generated an earthquake-like accelerogram whose response spectrum is very similar to that In Kegulatory Gulde 1.60. ${ }^{11}$ This similarity ensureg tnat our accelerogram nas the characteristics of many past eartnquakes and therefore provides a sound basis for comparing resultant floor spectra. The accelerogram was developed with tne code SI.REAR. ${ }^{16}$ It has a 30-s duration, has approximately $12 \mathrm{~s}$ of strong motion, has a maximum ground acceleration of $1 \mathrm{~g}$, and consists of 5000 points spaced $0.006 \mathrm{~s}$ apart.

Flgure 15 shows the $4 \%$ damped response spectrum of our syntnetic free-field ground motion and the $4 \%$ horizontal spectrum from Regulatory Guide 1.60. Ine figure illustrates inat, wnile the agreement is not precise, the spectral content of the synthetic eartnquake is adequate for our purposes. The response spectra of the artificial ground motion was used as input to the approximate methods.

Figure 15 shows that the Regulatory Guide 1.60 vertical and norizontal spectra are very similar. They are identical, in fact, over the range of NOFFF natural frequencies. Therefore, we tlected to use the same synthetic ground motion for the vertfcal and horfzontal filoor-specra calculations.

\section{Building Nodels}

Table 9 lists the material properties used in formulating the calculational models for both horizontal and vertical response. Four percent of critical damping is appropriate for the reinforced concrete MOFFP structure and was used for all calculations of building response. Our soft-soil naterial properties correspond to the lower limit of shear-wave speed for the range that is normally consifered intermediate. Our hard-soil-shearwave speed is at the lower lintt of the hard range. The purpose of 


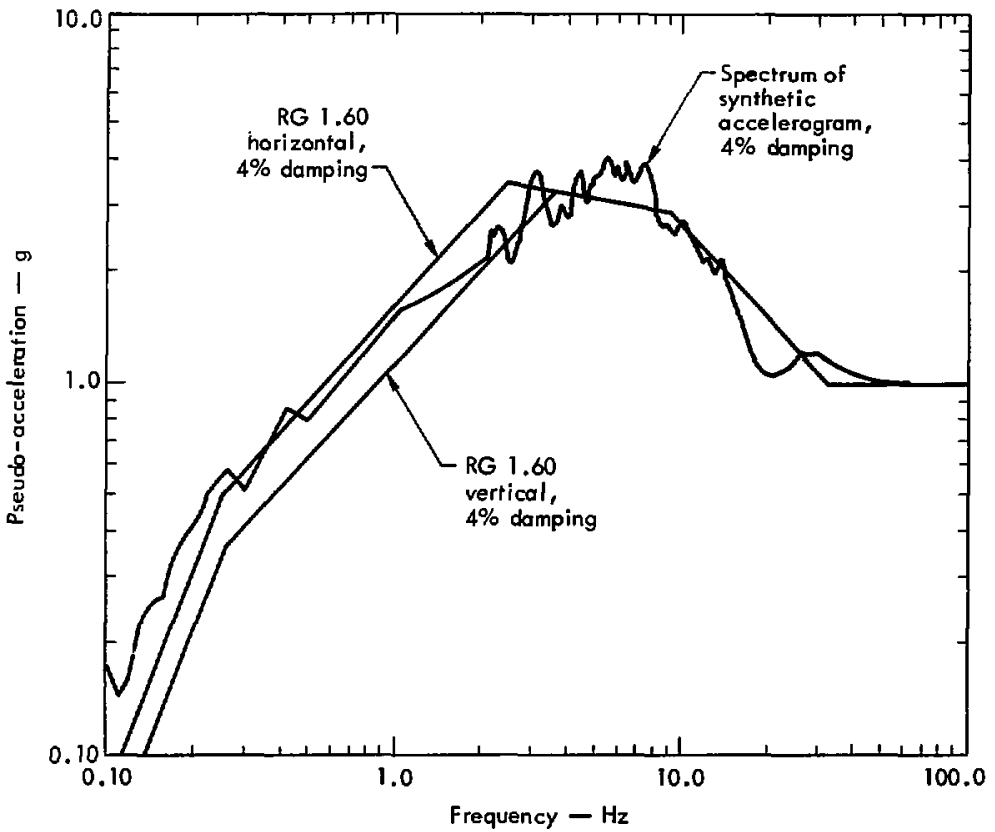

Fig. 15. Response spectrum of synthetic acceleration compared to Regulatory Guide 1.60 .

Table 9. Matertal properties for MOFFP analytical models.

\begin{tabular}{|c|c|c|c|c|c|c|}
\hline Material & $\begin{array}{c}\text { Weight } \\
\text { density, } \\
\gamma \\
\left(1 \mathrm{~b} / \mathrm{ft}^{3}\right)\end{array}$ & $\begin{array}{c}\text { Shear- } \\
\text { wave } \\
\text { speed, } \\
V_{s} \\
(\mathrm{ft} / \mathrm{s})\end{array}$ & $\begin{array}{c}\text { Young's } \\
\text { modulus, } \\
E \\
\text { (kips/in. }{ }^{2} \text { ) }\end{array}$ & $\begin{array}{c}\text { Shear } \\
\text { modulus, } \\
\text { G } \\
\text { (kips/1n. }{ }^{2} \text { ) }\end{array}$ & $\begin{array}{c}\text { Poisson's } \\
\text { rat } 10, \\
v\end{array}$ & $\begin{array}{c}\text { DampIng } \\
\text { ratio } \\
\text { (z) }\end{array}$ \\
\hline Concrete & 150 & --- & 3000 & 1200 & 0.25 & 4 \\
\hline Sof $t$ so 11 & 125 & 1500 & 164 & 60.6 & 0.35 & 4 \\
\hline Hard soil & 125 & 3500 & 891 & 330 & 0.35 & 4 \\
\hline
\end{tabular}


varying the soil properties was to

make the floor-spectra comparisons

extend over a range of site conditions considered representative of future HOFFP plants.

FIgure 16 shows the MOFFP analytical model used for horizontal response calculations. Note that the only difference between the softand hard-soil models is the value of the soil springs at the base. The MOFFP is symetrlc in plan, and the floors are relatively rigid in their plane. Therefore, a simple beam model 1 s adequate. The masses, $m_{1}$ througin $\mathrm{m}_{3}$, and inertias, $I_{1}$ through

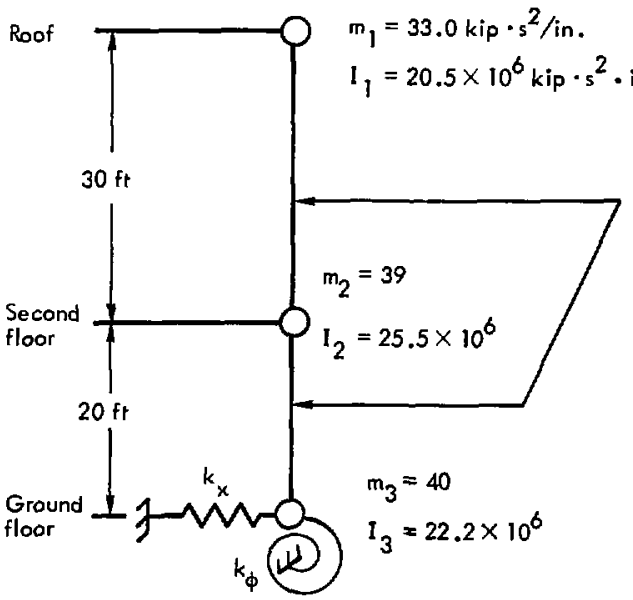

Concrere beam elements (massless)

Shear area $=9 \times 10^{4}$ in..$^{2}$

Bending inertia =

Soil springs

\begin{tabular}{|c|c|c|}
\cline { 2 - 3 } \multicolumn{1}{c|}{} & $\begin{array}{c}k_{x} \\
\text { (kips/in.) }\end{array}$ & $\begin{array}{c}k_{\phi} \\
\text { (in...kip/rad) }\end{array}$ \\
\hline Soft soil & $3.97 \times 10^{5}$ & $7.46 \times 10^{11}$ \\
Hard soil & $21.6 \times 10^{5}$ & $40.6 \times 10^{11}$ \\
\hline
\end{tabular}

Fig. 16. Analytical model for WOFFP hortzontal Iesponse. 
$I_{3}$, represent the taass and rotational inertia of the building roof, floors, and cributary wall areas. The lateral stiffening effect of the interior: columis and partitions is negligible. The beam-element shear area represents that of the sidewalls. The bending inercia is that of the entire perinter wall. The soil springs were calculated by the procedures recommended by Writman and Richart. ${ }^{17}$

Figure 17 snows the analyrical model used for vertical NuFFP response calculations. Here again, tue only difference between the soft- and hard-soil models is the value of che soll springs. In formulating chis model it was important to include the vertical bending action of the upper-floor and roof slabs. Uur model allows tor this efrect and yet provides a measure of economy in computing and modeling time. The model shown in Fig. 17 represents a 30-ft-wide strip of the HOFFP.

Figure 18 shows the origin of the strip model. Because the building is symuetric, it was recessary to model only one-nalf the length of the strif (105 fr) with the addition of

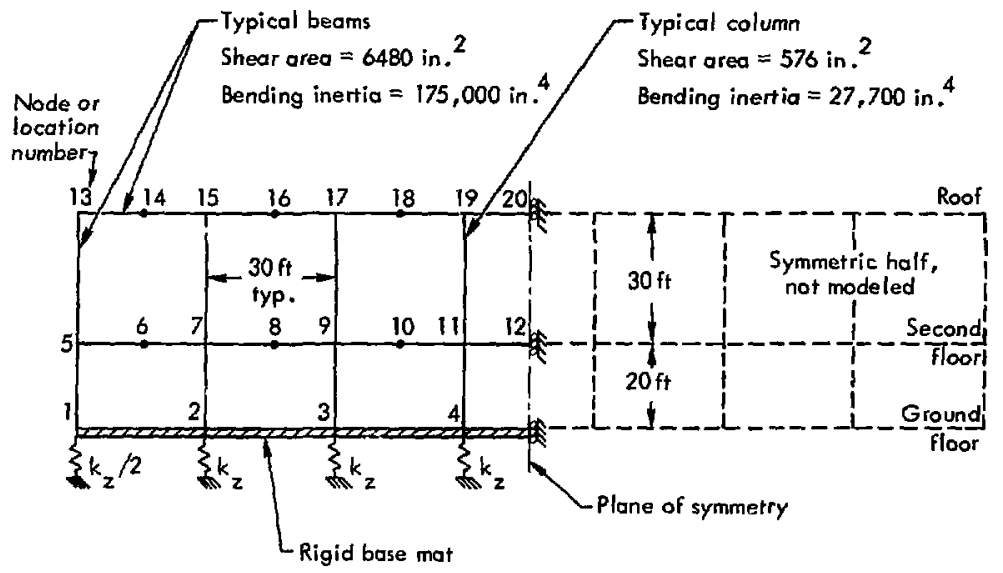

Fig. 17. Analytical model for MOFFP vertical response, elevation view. Soll

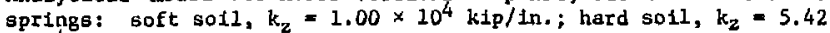
$\times 10^{4} \mathrm{kip} / \mathrm{in}$. 


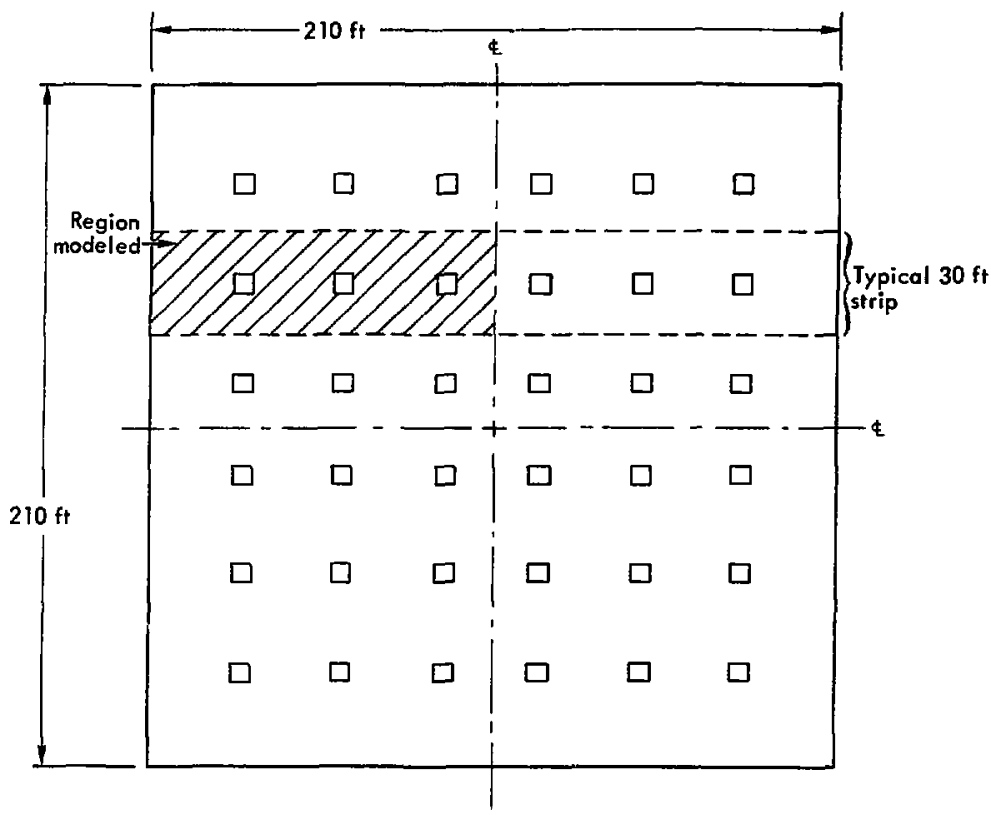

Fig. 16. Basts for the vertical AWFFP model, plan view.

aymmetric boundary conditions at the centerline as shown. The intertor vertical elements are the 24- $\times 24-1$. columins. The horizontal elements and exterior vertical elements (at the left) are beams 18 in. thick by $30 \mathrm{ft}$ wide. The base nat has been made artificially stiff to account for the supporting effect of the underlying soll.

The soil springs, $k_{2}$, represent the approprlate fraction of the overall soll spring for the building. They were calculatel as follows. The vertical soll spring for the entire 210- $\times 210-f t$ foundation was computed by the method in Ref. 17. The $\mathrm{k}_{2}$ shown in $\mathrm{FIg}$. 17 represents the fractional value of the overall spring for a $30-\times 30-f t$ section of the slab (that $1 s, k_{z}$ overall $/ 49$ ).

\section{Tine-History Method}

All the time-history analyses 
were performed in the same manner. We u.ed the SAPIV fintte-element $\operatorname{code}^{18}$ to make the calculations on a CUC-7600 compucer. We used the direct-integration scheme with the free-fleld-ground-motion accelerogram described above as input and $4 \%$ of critical viscous damping.

Because che equations of motion are formulated in terms of relative displacements, the accelerations output by $S_{H} P I V$ are relative to free-field. The absolute acceleration time-history was obtained by a postprocessing operation that added the ground acceleration to the structure acceleration at each time step. The final step was to calculate the pseuda-acceleration response spectrum of the motion at each degree of freedon of 1nterest. This was done for $0.5 \%$ of cricical (equipment) damping.

The time-history-dertved floor response spectra are shown in Figs. 19 and 20. Figure 19 shows the horlzontal floor spectra assoclated with soft- and hard-soil models. For the most part, the horfzontal spectra are dominated by the fundamental frequency of the bullding. The one exception is the ground-floor spectrum of the hardsoll model. In this case, the. 15-g peak occurs at $5.3 \mathrm{~Hz}$ and results from a "spike" in the response spectrum of the free-field ground motion at this frequency. The 5.3- Hz peak can be seen in the other floor spectra, but does not dominate when the modal response is more evident. The uneven character of the spectrum of the Input motion also accounts for the split resonance peak occurring in the soft-soil horizontal spectra. Note In FIg. 19a that there appears to be two closely spaced resonances. In actuality there is a "valley" in the spectrum of the input motion near the fundamental frequency of the bullding. Figure 20 shows the vertical MOFFP floor spectra calculated by the time-history method. We chose nodes 2, 8, and 16 of our vertical model for floor-spectra calculations. They are representative of the ground floor, second floor, and roof, respectively. The split resonance phenomenon observed in the horizontal soft-soil spectra is also evident in the vertical soft-soil calculations.

\section{Approximate Methods}

The Kapur and Blggs approximate methods for generating floor spectra are well documented in Refs, 13 and 14. However, for completeness the two methods are outlined in the appendix to this report.

There are two essential differences between the two methods. The 

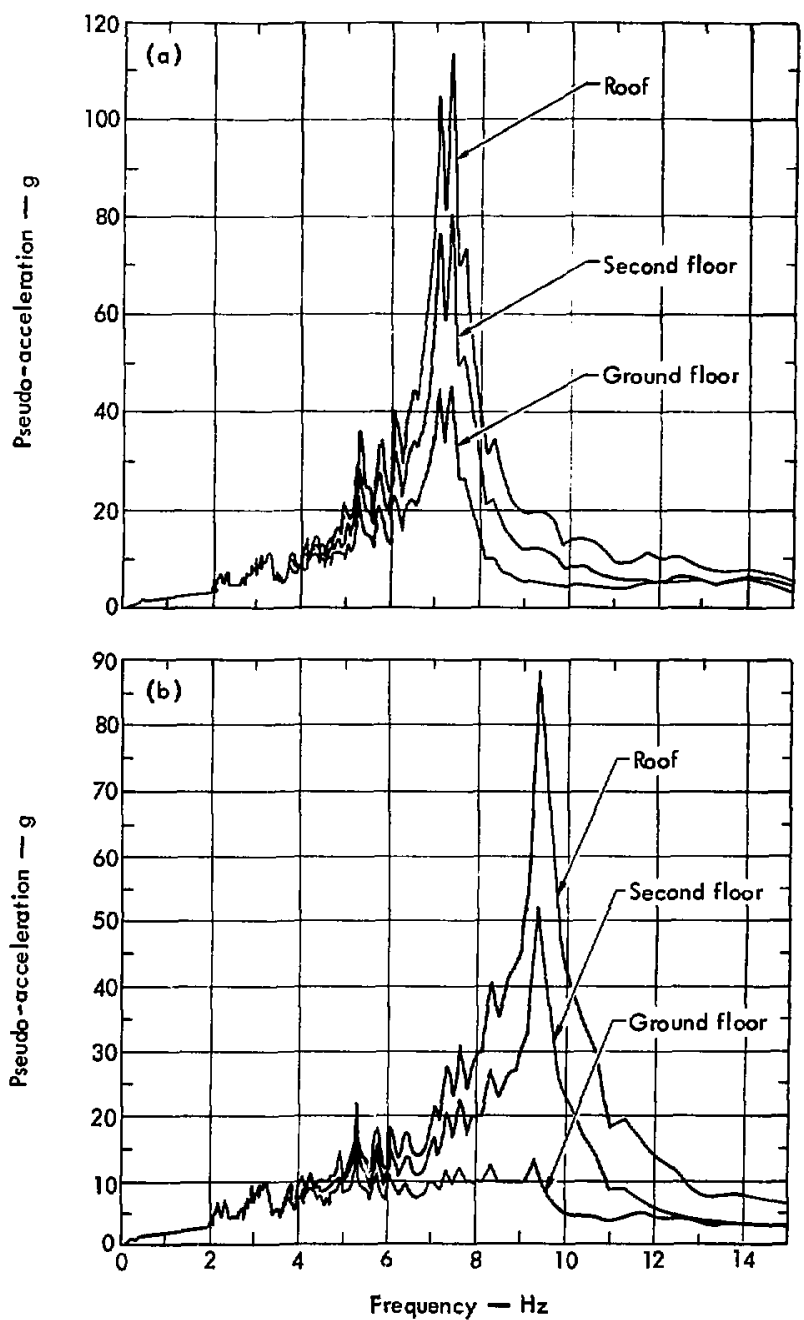

F1g. 19. Time-history-derived horizontal floor spectra, $1 / 2 \%$ damping. (a) Soft soll. (b) hard soll. 

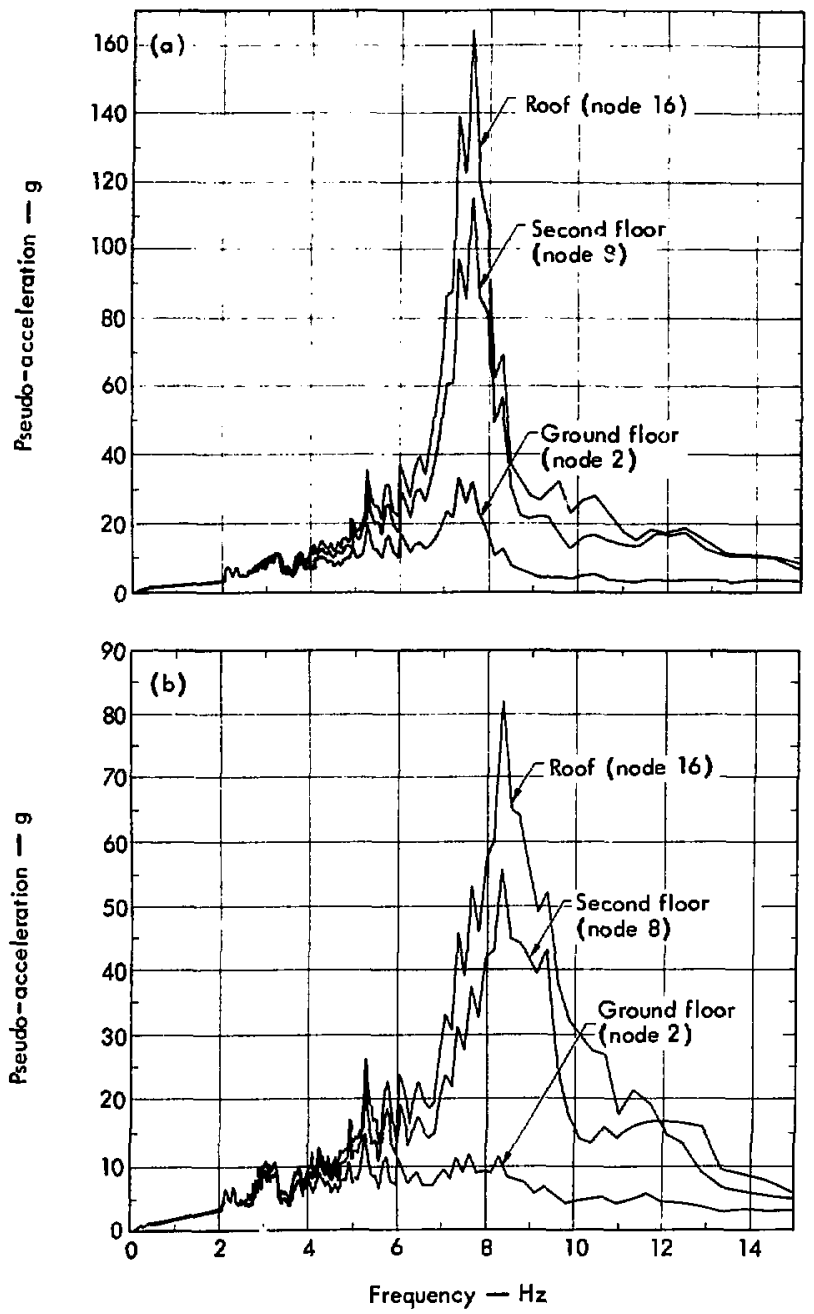

Fig. 20. Time-history-derived vertical floor spectra, $1 / 2 \%$ damping. (a) Soft soll. (b) Hard soil. 
first is that Kapur's method is based on a hypothetical upper $11 \mathrm{mit}$ to the amplification of the bullding and/or ground motion; Biggs' amplification factors are based on the envelope of several time-history analyses of a two-degree-of-freedom system. Kapur used a time-history analysis to estimate amplification factors only at equipment-building resonance.

The second difference is that Kapur's method involves artificially broadenting the resonance peaks in the Eloor spectra by $\pm 10 \%$; Biggs' method does not broaden the peaks.

To our knowledge Biggs' method is publiehed for only one set of structure-equipment damping values: 4.0 and $0.5 \%$. Kapur's method is published for a range of structureequipment damplag values that does not include the two that Blggs reports. We therefore extrapolated Kapur's resonance amplification factor to 4.0 and $0.5 \%$ atructure-eguipment damping to facilitate the compartson. The extrapolated amplification value only affects Kapur's floor spectra near bullding-equipment resonance.

As noted previotsly, both methods require a modal analysis of the building and the response spectra of the free-fielo ground motion. The modal analyses required by the approximate methods were accomplished with the SAPIV code. The analytical models used were 1dentical to those used in the time-history calculations.

Figure 21 shows the results of the modal analysis of the two horizontal models. In both the softand hard-soll cases, the four lowest natural frequencies were input to the approximate methods. None of the modes were closely spaced.

Table 10 gives the modal-analysis data for the two vertical response models. Here, the model was more complex, and therefore the resulting mode shapes were more complex. of the 15 frequencies obtained for the soft- and hard-soll models, 10 were chosen for Input to the approximate methods. The frequencles were chosen for maximum response, based on the participation factor, $\Gamma$, the elgenvector, $\varphi$, and preliminary calculatlons of approxinate floor spectra.

It is of interest to note that many of the modes of the vertical model are closely spaced under the criterla In Regulatory Guide $1.92 .^{19}$ This fact affects the approximate floor spectra because, as we point out In the appendix, the criterla and summing procedure in the Guide are used in the Biggs and Kapur methods.

In performing the analysis we discovered that in some instances the approximace vertical spectra could 


\begin{tabular}{|c|c|c|c|c|c|c|c|c|c|}
\hline \multicolumn{5}{|c|}{ Soft soil } & \multicolumn{5}{|c|}{ Hard soil } \\
\hline \multirow{2}{*}{$\begin{array}{c}F_{\ln } \\
\left(\mathrm{Hz}_{z}\right)\end{array}$} & \multirow[b]{2}{*}{$\Gamma_{\ln }$} & \multicolumn{3}{|c|}{$\phi_{\mathrm{sn}}$} & \multirow{2}{*}{$\begin{array}{c}f^{\prime} \ln \\
\left(H_{z}\right)\end{array}$} & \multirow[b]{2}{*}{$\Gamma_{\ln }$} & \multicolumn{3}{|c|}{$\phi_{s n}$} \\
\hline & & $s=1$ & 2 & 3 & & & $s=1$ & 2 & 3 \\
\hline 7.30 & 9.94 & 0.128 & 0.0925 & 0.0526 & 9.69 & 8.71 & 0.147 & 0.0834 & 0.0150 \\
\hline 14.8 & 2.59 & 0.0364 & 0.0395 & 0.0563 & 22.8 & 3.43 & 0.0797 & 0.122 & 0.0326 \\
\hline 20.0 & 2.21 & 0.104 & 0.0549 & 0.0878 & 26.4 & 0.741 & 0.0475 & 0.0495 & 0.0094 \\
\hline 28.9 & 1.29 & 0.0418 & 0.112 & 0.107 & 41.5 & 4.89 & 0.0055 & 0.0369 & 0.154 \\
\hline
\end{tabular}

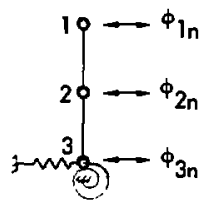

F1g. 21. MOFFP horizontal response model, normal mode data input to approximate floor spectra methods, lowest four normal modes. $\Gamma$, modal participation factor; $\phi$, eigenvector. (See Appencizix for additional def Init Ions.)

actually be Increased by leaving out one of the normal modes of the buildIng. This resulted because: (1) the discarded mode was of minor importance to the building response and (2) the closely spaced modes were grouped in a different fashion by the algorithm In Regulatory Guide 1.92. We note this anomaly here as a matter of general interest.

Figures 22 through 25 show the MOFFP floor spectra derived by the
Kapur and Biggs approximate methods. Each figure shows the three floor spectra for a particular soll stiffness, method, and direction.

The overall appearance of the Biggs spectra is much the same as the time-history spectra. The Kapur spectra, on the other hand, are characterlzed by very broad, flat resonance peaks. This feature results from the $\pm 10 \%$ peak broadening that is part of the Kapur method. 
Table 10. Normal-mode data for MOFFP vertical response model.

\begin{tabular}{|c|c|c|c|c|c|c|c|c|c|c|}
\hline \multirow{3}{*}{$\begin{array}{l}\text { Mode } \\
\text { No. } \\
\text { "n" }\end{array}$} & \multicolumn{5}{|c|}{ Soft soll } & \multicolumn{5}{|c|}{ Hard soil } \\
\hline & \multirow{2}{*}{$\begin{array}{l}\mathrm{f}_{1 \mathrm{n}} \\
\left(\mathrm{H}_{2}\right)\end{array}$} & \multirow{2}{*}{$\Gamma_{\ln }$} & \multicolumn{3}{|c|}{$\phi_{\text {sn }}$} & \multirow{2}{*}{$\mathrm{F}_{\ln }$} & \multirow{2}{*}{$\Gamma_{\ln }$} & \multicolumn{3}{|c|}{$\phi_{\text {sn }}$} \\
\hline & & & $S=2$ & 8 & 16 & & & $S=2$ & 8 & 16 \\
\hline $1^{a, b}$ & 7.70 & .987 & .084 & .081 & 1.16 & 7.72 & .039 & .0056 & .192 & .924 \\
\hline $2^{a, b}$ & 7.74 & 2.07 & .124 & .566 & .333 & 8.29 & .031 & .0035 & .556 & .507 \\
\hline $3^{a, b, c}$ & 7.98 & .088 & .102 & .471 & .744 & 8.42 & .303 & .020 & .934 & 1.16 \\
\hline $4^{a, b, c}$ & 8.19 & .328 & .072 & .453 & .503 & 8.82 & 1.35 & .0049 & .270 & .495 \\
\hline $5^{a, b, c}$ & 8.44 & .484 & .059 & .803 & .532 & 9.15 & 1.17 & .035 & .374 & .235 \\
\hline $6^{a, b, c}$ & 9.63 & .234 & .029 & .866 & .315 & 9.89 & .502 & .018 & .908 & .385 \\
\hline $7^{a, b}$ & 11.43 & .362 & .080 & .873 & .577 & 11.77 & .253 & .022 & .805 & .440 \\
\hline $8^{a, b, c}$ & 12.67 & .669 & .062 & .471 & .349 & 13.08 & .509 & .015 & .848 & .468 \\
\hline $9^{\mathrm{a}}$ & 13.23 & .256 & $-0-$ & .583 & .418 & 16.88 & .089 & .047 & .059 & .105 \\
\hline $10^{b, c}$ & 16.04 & .059 & .151 & .083 & .150 & 19.67 & .229 & .057 & .291 & .517 \\
\hline $11^{c}$ & 18.48 & .106 & .315 & .382 & .509 & 21.31 & .974 & .058 & .037 & .026 \\
\hline $12^{a, b, c}$ & 19.49 & .787 & .251 & .400 & .399 & 22.26 & .752 & .052 & .258 & .447 \\
\hline 13 & 25.74 & .482 & .220 & .019 & .256 & 34.79 & .047 & .156 & .018 & .011 \\
\hline $14^{\mathrm{C}}$ & 27.04 & .158 & .680 & .055 & .174 & 35.47 & .159 & .248 & .123 & .074 \\
\hline $15^{\mathrm{c}}$ & 29.07 & .051 & .552 & .009 & .006 & 36.09 & .709 & .138 & .124 & .080 \\
\hline
\end{tabular}

${ }^{a}$ Soft-soll modes used.

DHard-sofl modes used, nodes 8 and 16.

${ }^{c}$ Hard-soll modes used, node 2 . 

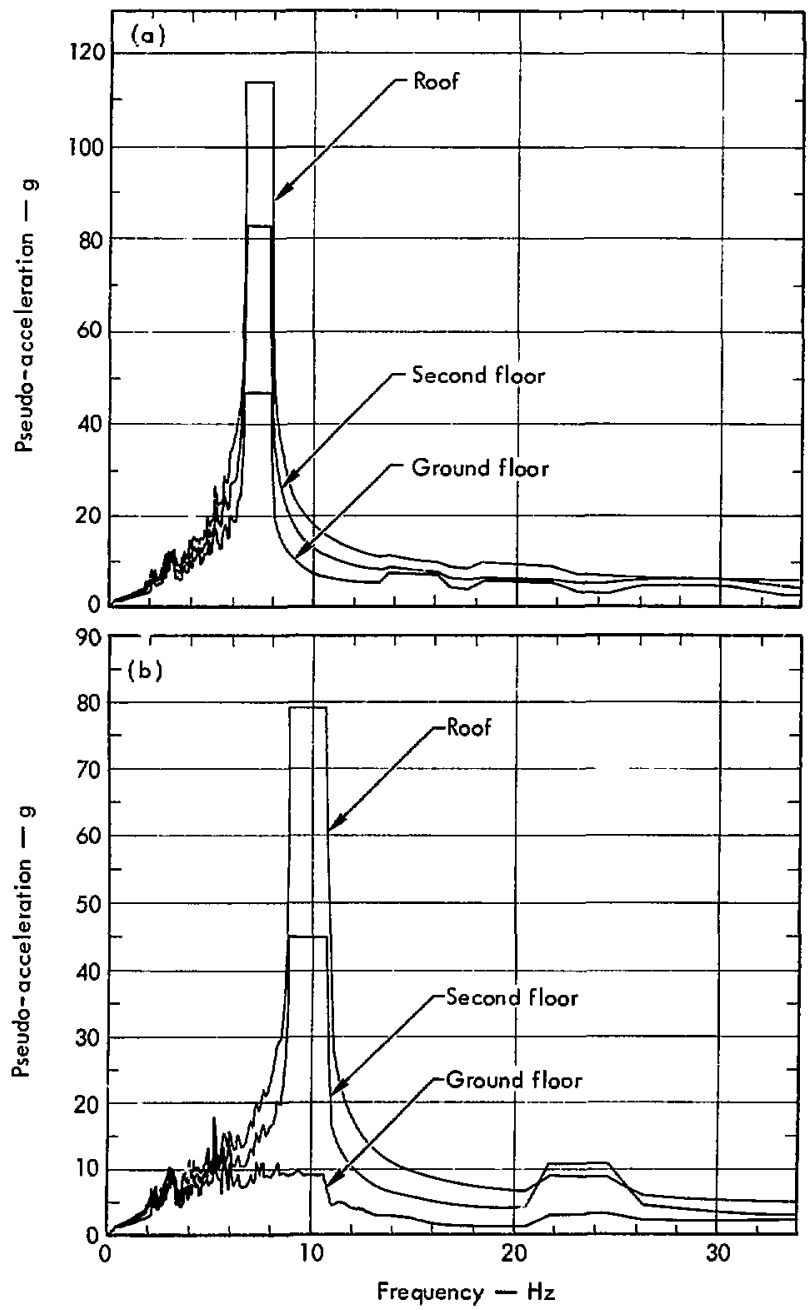

FIg. 22. MOFFP horizontal floor spectra by Kapur's method, $1 / 2 \%$ equipment damping. (a) Soft-goil model.

(b) Hard-sol1 mode1. 

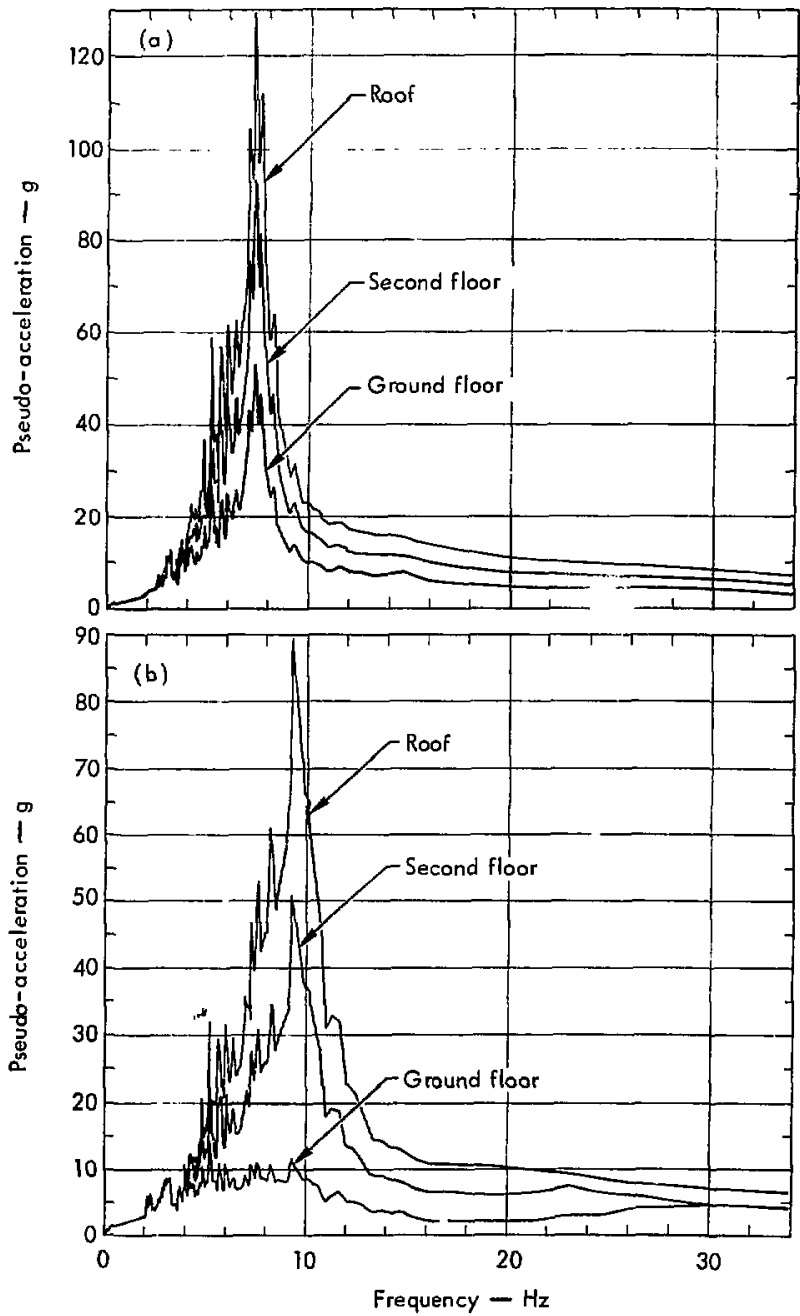

F1g. 23. MOFFP hortzontal floor spectra by B1ggs' method, $1 / 2 \%$ equipment damping. (a) Soft-so11 model. (b) Hard-soll model. 

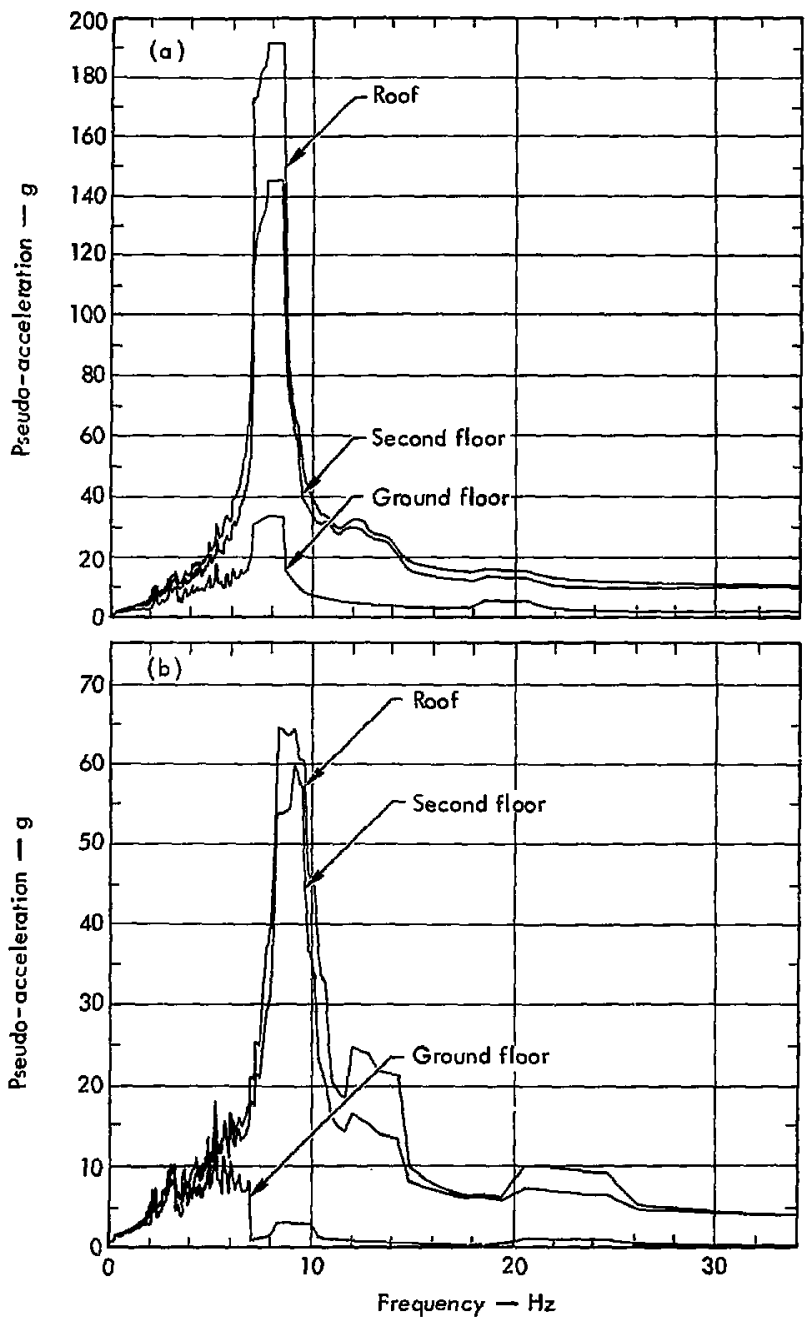

F1g. 24. MOFFP vertical floor spectra by Kapur's method, 1/2\% equipment damplng. (a) Soft-soll model, (b) Hard-soll madel. 

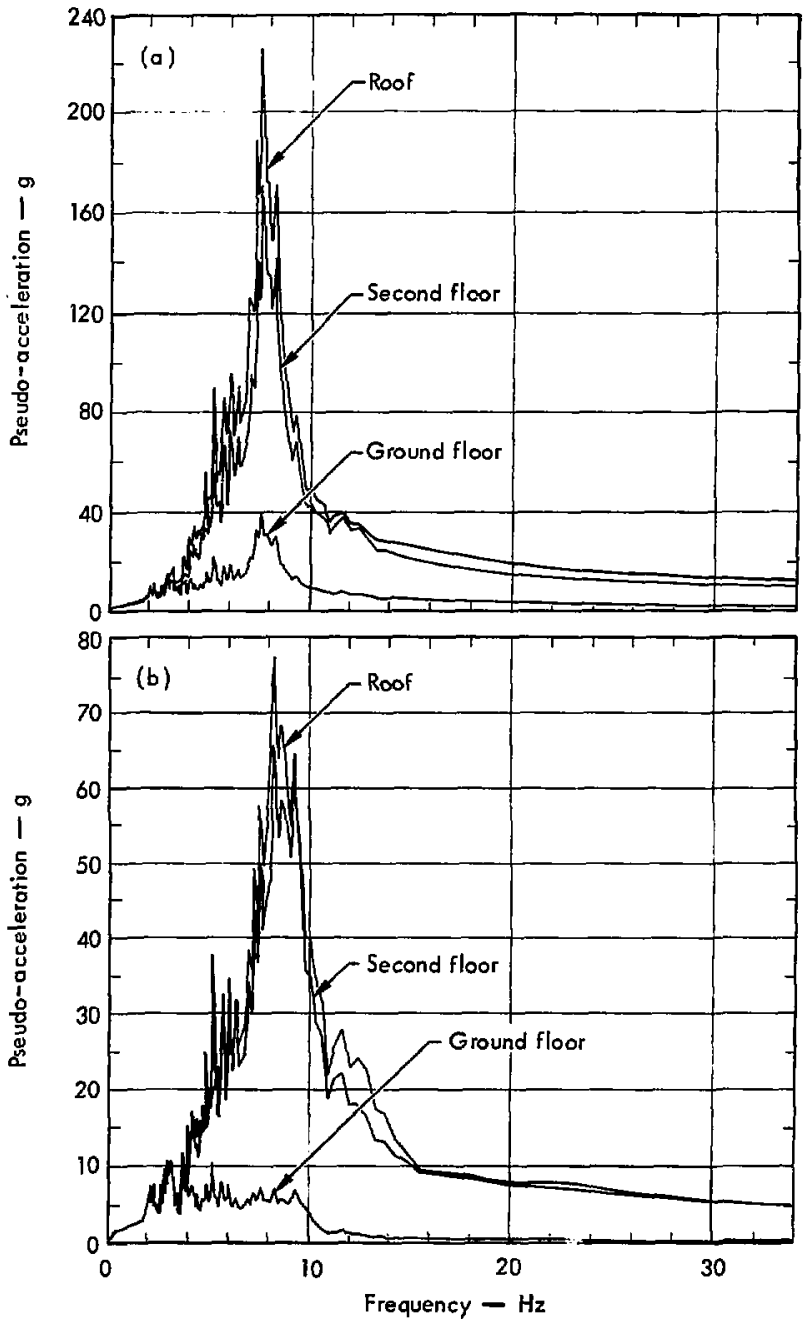

Fig. 25. MOFFP vertical floor spectra by Biggs' method, 1/2\% equipment dampling. (a) Soft-soll model. (b) Hard-soil model. 
CONPARISON OF INTHODS

\section{Floor Spectra}

Normally, the designer will draw smooth response spectra that envelope the calculated spectra. These smoothed curves are a much more convenient and reasonable tool for design purposes. Also, the primary resonance peaks of the floor spectra are artificially broadened for design purposes to allow for uncertainty in building frequencies. We felt these measures would blur our compartson, particularly so since the spectrum of tine input motion was not smooth. Therefore, we did not make these modifications on our floor spectra. Kapur's method already had a $\pm 10 \%-$ peak-broadening feature butlt into it, but rather than tamper with the method, we left it in.

All floor spectra were calculated at the same set of frequencles. The set contalned 198 points between 0.10 and $33 \mathrm{~Hz}$. Numertcal comparison of the floor spectra was somewhat complicated by the jagged nature of the input spectrum. This problem was overcome by plotting the ratio of each approximate floor spectrum to the corresponding time-historyspectrum vs. Erequency.

We feel that these ratio plots, shown In Figs, 26 through 29, have two Important Iimitations. First,
The artificial peak broadening in Kapur's method can cause a great deal of conservatism in the regions on either side of the ticllding natural frequencies. Second, as the ratio curves indicate, both the Kapur and Biggs methods tend to produce very unconservative horizontal and vertical spectra at the ground floor when the soll is hard. The base mat moves, for the most part, as the soll moves. To model this situation correctly, many more of the higher building frequencies need to be Included. We did not include all the building frequencles in the approximate-floor-spectra calculations and the resulting spectra at the ground level were too low at some frequencies.

Excluding the cases above from consideration, the ratio plots Indicate that the Kapur floor spectra range from 0.6 to 4.5 times the timehistory floor spectra; Biggs' range from 0.8 to 3.7 . In general, the methods tend to estimate the spectrum at the fundamental building frequency very closely and to overestimate $1 t$ at higher frequencies.

As currently formulated, the approximate-floor-spectra methods of kapur and $\mathrm{BIg}$ 's do not provide a reasonably constant degree of conservatism. Additional study and modification of these methods could 

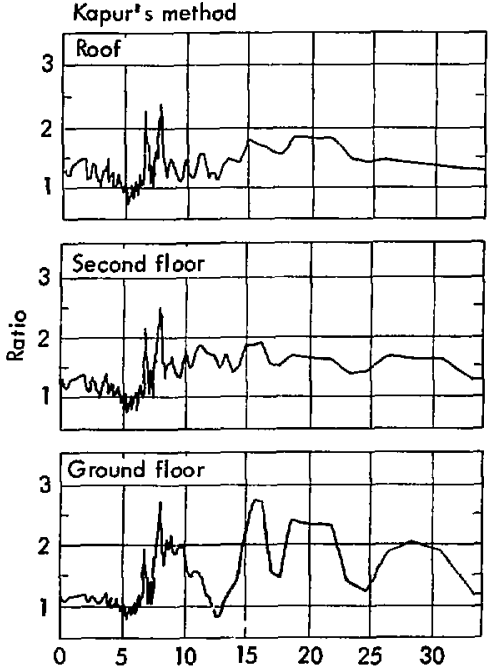

Frequency $-\mathrm{Hz}$
Biggs' method
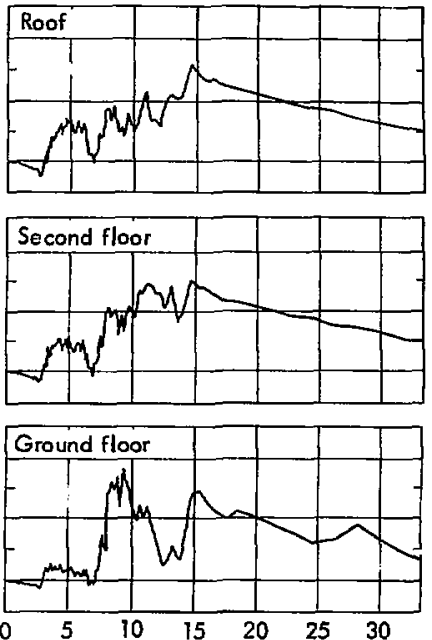

Frequency $-\mathrm{Hz}$

Fig. 26. Ratio of approxlmate to time-hiscory floor spectra, horizontal motions, soft soll.

eliminate, for the most part, the reglons where the spectra are unconservative. However, the designer would still be faced with a degree of method-Introduced uncertalncy and at the same time a potential designload Increase of 300 to $400 \%$.

\section{Intangtbles}

We noted earlier that there are three reasons for using an approximate method instead of the time-history method: (1) no synthetic accelerogram is needed; (2) an approximate method Is less complex; and (3) less analyst and computer time is required. However, our expertence indicates that these reasons may not be valid.

It is true that the approximate methods do not require generation of a synthetic accelerogram. However, computer programs that produce such tailored accelerograms have lately become more widespread and more satisfactory in performance. $16,20,21$ 

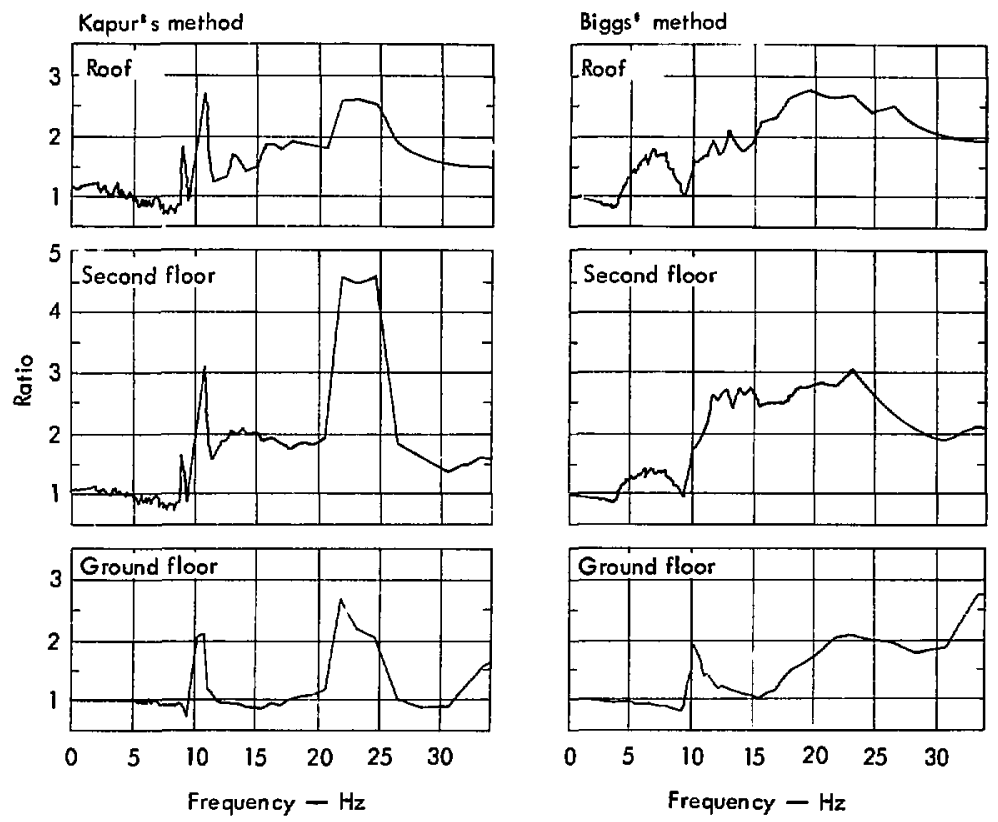

Fig. 27. Ratio of approximate to time-history floor spectra, horizontal motions, hard soll.

The notion that the tinie-history procedure is more complex seems debatable. The most demanding task facing the analyat is to formulate a reasonable analytical model, and he must do this with any of the methods. The time-history calculation, although requiring more tine, does not greatly Increase complexity.
The time-history approach does require more analyst and computer time. We estimate that it costs twice as much to perform as either of the approximate methods. However, the total dollar cost for floor spectra would still be a very small fraction of the value of a MOFFP. 
Kopur's method
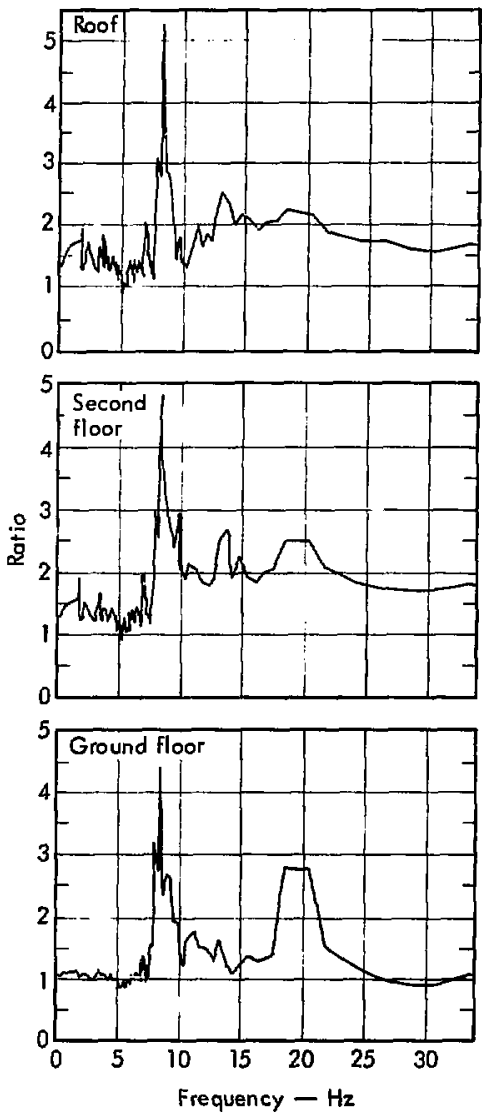

Biggs' method
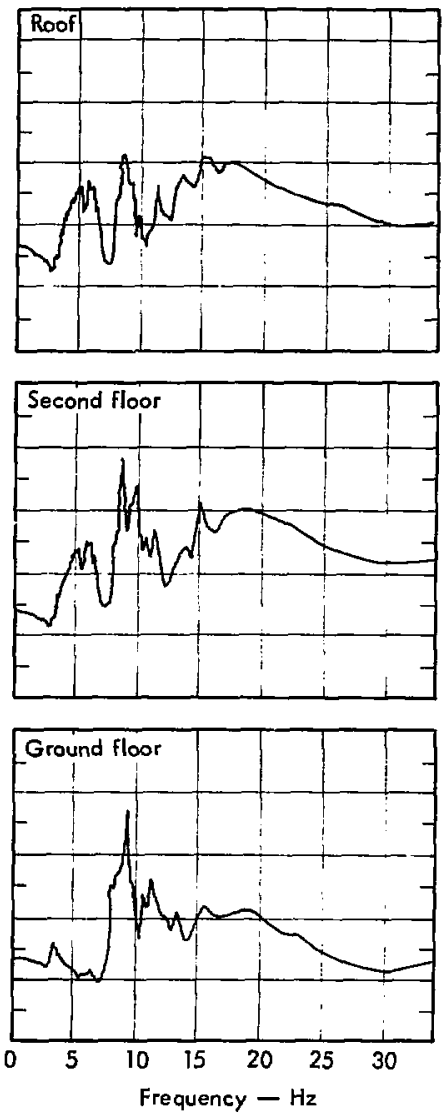

Fig. 28, Ratio of approximate to time-inistory floor spectra, vertical motions, soft soll. 

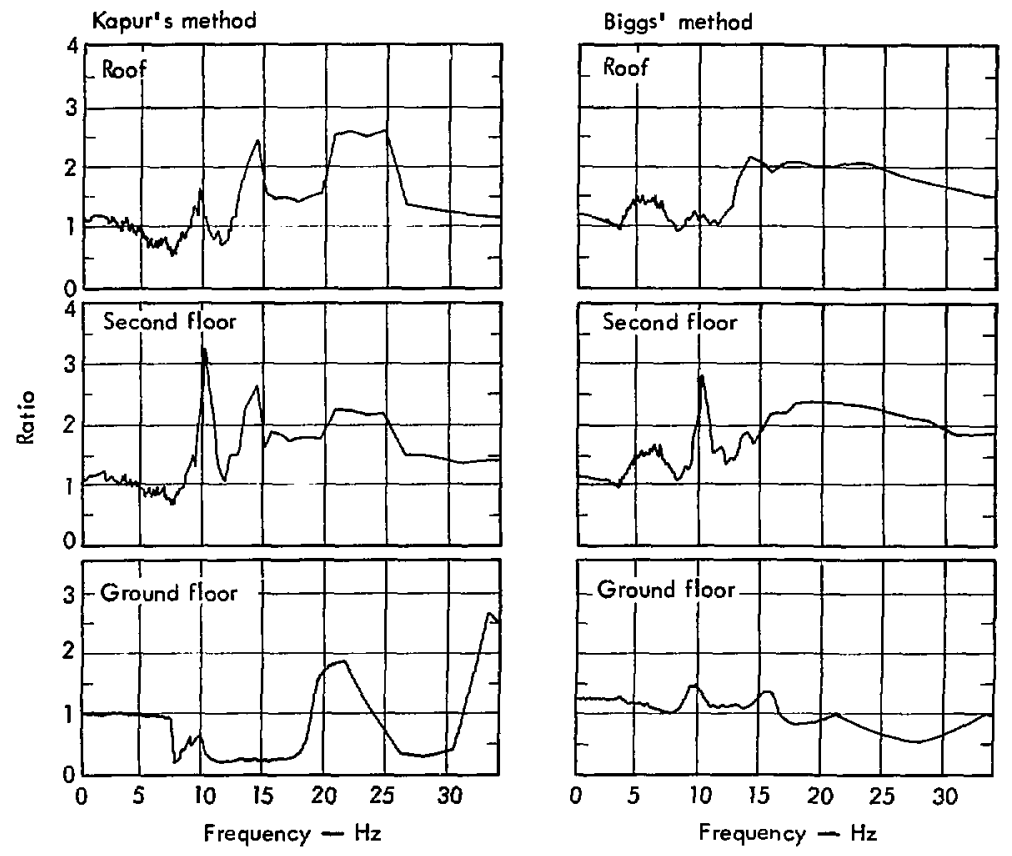

Fig. 29. Ratio of approximate to time-history floor spectra, vertical motions, hard soll. 
CONCLUSIONS

Our study Indicates that the timehistory method of generating floor spectra is the most suitable method for fuel fabrication factlities and other installations of similar value and 1mportance. The basts of this conclusion can be summartzed as follows :

- The approximate methods may yield floor spectra that are 3-to-4 times the time-history spectra at some frequencles.

2. Methods for generating the synthetic ground motion required by the time-history method are becoming widely ava1lable.

3. The time-history method results in a minor increase in complextry and a cost increase that is minute compared to the project cost.

\section{Acknowledgments}

The authors wish to acknowledge the assistance and encouragement of V.N. Karpenko, Leader, and C.E. Walter, Ueputy Leader, Nuclear Test Engineering Division, Mechanical Engineering Department, Lawrence Livermore Laboratory.

We would like to particularly thank K.G. Steyer, USNRC, Office of Standards bevelopment, for providing guldance throughout this study.

We also appreclate the time spent by K.M. Barry and his assoctates at the Ralph if. Parsons Company. Their assistance and cooperation have been most helpful. 


\section{References}

1. License Application, Recycle Fuels Plant, Westinghouse Nuclear Fuel Viviston, Pittsburgh, PA (1973), bocket No. 70-1432.

2. L.C. Schwendiman, J. Hishima, and G.E. Stegen, Airborne Plutonium Release Postulated for Serious Accldents in a Generic Recycle Mixed-oxide Fuel Fabrication Plant, Battelle Pacific Northwest Laboratories draft report, Richland, is (November 1974).

3. F.J. Tokarz, R.C. Hurray, and H.C. Sorensen, Seismic Response and Fallure Analyses of a ilixed-Oxide Fuel Fabrication Plant, Lawrence Livermore Laboratory Rept. UCRL-51755 (1975).

4. F.J. Tokarz, R.C. Murray, D.F. Arthur, W.W. Feng, I.H. Wight, and M. Zaslawsky, Evaluation of Methods for Selsmic Analysis of Nuclear Fuel Reprocessing Plants, Lawrence Livermore Laboratory Rept. UCRL-51802, Part 1 (1975).

b. DegIgn Basis Tornado for Nuclear Power Plants, USAEC Regulatory Guide $1.76(1974)$.

6. Building Code Requirements for Minimum Design Loads in Bulldings and Other Structures, American National Standards Institute Rept. ANSI A58.1-1972.

7. Code of Federal Rugulations, Title 10, Part 71, Transport of Licensed Haterials; see also Eederal Register, Vol. 30, pp. 15748-15759, December 21, 1965.

b. Standard Format and Content of Safety Analysts Reports for Nuclear Power Plants (Revlsion I), prepared by the Regulatory Staff, USAEC (1972).

9. C.A. Burchsted and A.B. Fuller, Design, Consczuction, and Testing HighEffictency alr Filtration Systems for Nuclear Applications, ORNL-NS IC-65 (1970).

10. Reactor Site Criteria: Appendix A, Selsmic and Geologic Siting Criteria for Nuclear Power Plants, USAEC Rept. 100FR100 (1973).

11. Design kesponse Spectra for Nuclear Power Plants, USAEC Regulatory Guide $1.60(1973)$.

12. Damping Values for Selsmic Design of Nuclear Power Plants, USAEC Regulatory Gulde 1.61 (1973).

13. Kanwar K. Kapur and Lawrence C. Shao, "Genecation of Selsmic Floor Response Spectra for lquipment Desing," Specialty Conference on Structural Deston of Nuclear Plant Fac1lities, December 17-18, 1973 (ASCE, ChIcago, 1973), Vol. 1, pp. 29-71. 
14. J.M. Blggs, "Selonic Response Spectra for Equipment Design In Nuclear Power Plants," Paper \#K4/7 F1rst International Conference on Structural ilechanles in Reactor Technology, Germany (1971).

15. J.M. Blggs and J.M. Roesset, "Seismic Analysis of Equipment Mounted on a Massive Structure," Selsmic Design for Nuclear Power Plants, R. J. Hansen, Ed. (MIT Press, Cambridge, MA, 1970), pp. 319-343.

16. W. Watabe, SIMEAR Generation of Simulated Earthquake, Natlonal Information Service, Earthquake Engineering, University of California, Berkeley, CA, jocument No. 09-573 (1972).

17. R.V. Whitman and F.E. RIchart, Jr, "Design Procedures for Dynamically Loaded Foundations," Journal of the Soll Mechanics and Foundation Division (November 1967).

18. K. Bathe, E.L. W1lson, and F.E. Peterson, SAPIy - A Structural Analysis Program for Static and Dynamic Response of Linear Structures, Earthquake Engineering Research Center, College of Engineering, University of California, Berkeley, CA, Rept. LERC 73-11 (1973).

19. Combination of Modes and Spatial Components in Selsmic Response Analysis, USAEC Regulatory Gu1de 1.92 (1974).

20. R.H. Scanlon, "Earthquake Time Historles and Response Spectra," ASCE, Journal of the Englneering Mechantes D1vision, 635 (August 1974).

21. C.A. Cornell and E.H. Vanmarcke, Art.1f Lcial Earthquake Motions for Design, Grystal River, Florida Site, report prepared for Weston Geophysical Research, Inc. (February 1972). 


\section{Appendix \\ Description of the Kapur and Biggs Approximate Methods}

Before describing each method, a definftion of terms is necessary. It should be noted that for clarity and uniformity we have changed some of the terminology used by the two authors, However, the mathematical intent is preserved exactly. Quantities required as input to the two methods are:

$$
\begin{aligned}
& f_{1 n}=\text { nth natural frequency }(\mathrm{Hz}) \\
& \text { of the building. (All } \\
& \text { first subscripts " } 1 \text { " and } \\
& \text { " } 2 \text { " refer to the building } \\
& \text { and equipment, } \\
& \text { respectively). } \\
& \mathrm{f}_{2} \text { = equipment frequency. } \\
& \Gamma_{\text {ln }} \text { = modal participation factor } \\
& \text { for mode } n \text {. } \\
& \psi_{\text {sn }}=\text { mode-shape value for mode } \\
& \text { n at modal point where }
\end{aligned}
$$$$
\text { equipment is supported, }
$$$$
S_{\text {lgn }} \text { acceleration value from }
$$
response spectrum of freefield ground motion at building frequency. $f_{1 n}$, and damping, $\xi_{1}$.

$\mathrm{S}_{2 \mathrm{~g}}$ = acceleration value from response spectrum of freefield ground motion ac equipment frequency, $\mathrm{f}_{2}$, and damping, $\xi_{2}$.

$$
\begin{aligned}
S_{g}= & \text { maximum ground accelera- } \\
& \text { tion of the free-field } \\
& \text { ground motion. }
\end{aligned}
$$

Output quantities defined (that is, floor spectra for equipment analysis) are:

$$
\begin{aligned}
s_{2 n}= & \text { contribution of the nth } \\
& \text { building frequency to the } \\
& \text { equipment response spectrum } \\
& \text { at equipment frequency, } f_{2} \cdot \\
S_{2}= & \text { acceleration value of the } \\
& \text { approximate floor spectrum } \\
& \text { obtained by summing the } \\
& S_{2 n} \text { in an appropriate } \\
& \text { manner. }
\end{aligned}
$$

KAPUR'S APPROXINATE METHOD

For each equiptment frequency of Incerest, $f_{2}$, perform the following:

1. For each aignificant building frequency, $n$ :

a. If $\frac{f_{1 n}}{f_{2}} \leq 0.9$, then $s_{2 n}$

- $\phi_{\mathrm{sn}} \Gamma_{1 \mathrm{n}} \mathrm{A}_{\mathrm{l}} \mathrm{s}_{1 \mathrm{gn}}$, where $A_{1}=1 /\left(1-\frac{f_{1 n}}{f_{2}}\right)$.

b. If $0.9<\frac{f_{1 n}}{f_{2}}<1.10$, use the equation for $S_{2 n}$ above where 
$A_{1}$ is taken from the appendix in Ref. 3. The value of $A_{1}$ depends on the structure and equipment damping and is not listed in Ref. 3 for $\xi_{1}=0.04$ and $\xi_{2}=0.005$. Enough values are provided so that it may easily be extrapolated. We determined $A_{1}$ to be 23.0 for 4 and $0.5 \%$ structure and equipment damping.

$$
\text { c. } \begin{aligned}
& \text { If } \frac{f_{1 n}}{f_{2}} \geq 1.10 \text {, then } s_{2 \pi} \\
& =\Phi_{s n} \Gamma_{l n}\left[A_{2}\left(s_{l_{g} n}^{2}-s_{g}^{2}\right)^{1 / 2}\right. \\
& \left.+s_{2 g}\right] \text {, where } A_{2} \\
& =1 /\left(\frac{f_{1 n}}{f_{2}}-1\right) .
\end{aligned}
$$

If, however, the lowest building frequency, $f_{11}$, is such that $\frac{f_{11}}{f_{2}} \geq 1.1$, then $s_{2 \pi}$ is calculated in a different manner:

$$
s_{2 n}-\phi_{s n} \Gamma_{l n} A_{2}\left(s_{l g n}^{2}-s_{g}^{2}\right)^{1 / 2} .
$$

2. When $S_{2 n}$ has been calculated for all the gignificant building frequencles, the contributions are summed as follows:

If, In step $1 c$ above $\frac{f_{11}}{f_{2}} \geq 1.1$, $\operatorname{tnen} s_{2}=\left[\sum_{n} s_{2 n}^{2}\right]^{1 / 2}+s_{2 g}$.

$$
\begin{aligned}
& \text { If } \frac{f_{1 l}}{f_{2}}<1.1, \text { then } \\
& s_{2}=\left[\sum s_{2 \pi}^{2}\right]^{-1 / 2} .
\end{aligned}
$$

Kapur recomnends that for closely spaced building modes, "the absolute sum of the closely spaced modes should be obtained before taking the square root of the sum of the squares with the other modal responses." In our study, we found closely spaced modes in tise verticai Iloor-spectra calculations. We therefore took Kapur's recomnendation and followed the guidelines set forth in Regulatory Gulde 1.92 for combination of modes. 19

\section{BIGGS' APPROXILATE METHOD*}

For each equipment frequency of interest, $f_{2}$, do the following:

1. For each significant building frequency, $n$ :

$$
\begin{aligned}
& \text { a. If } \frac{f_{1 n}}{f_{2}}<0.90 \text {, compute } \\
& S_{2 \mathrm{n}}^{\prime}=\Phi_{\text {sn }} \Gamma_{1 \mathrm{n}} S_{1 \text { gn }} A_{3} \text {, where }
\end{aligned}
$$

\footnotetext{
For the reader who decides to refer to Biggs' paper (Ref. 14) it is worthwhile to point out a typographica] error in that document. In our copy of this paper, on page 333, the autnor's references to his Figs. 2 and 3 have been reversed [that is, step 2 (A) should refer to Fig. 3 and step $2(B)$ should refer to Fig. 2].
} 
$A_{3}$ is read from the author's Fig. 3 and our Fig. A-l. One enters the plot with the

Erequency ratio $\mathrm{f}_{1 \mathrm{n}} / \mathrm{f}_{2}$ and determines the corresponding amplification factor.

$h$ If $\frac{f_{1 n}}{f_{2}}>0.50$, compute

$S_{2 \mathrm{n}}^{\prime \prime}=\frac{\phi_{\mathrm{sn}} \Gamma_{1 \mathrm{n}}}{\mathrm{C}} \mathrm{A}_{2} \mathrm{~s}_{2 \mathrm{~g}}$, where the value of $A_{2}$ is read from the author's Fig. 2 and our Fig. $\mathrm{d}-1$. The value of $\mathrm{C}$ is determined as follows: If $\frac{\mathrm{f}_{\mathrm{ln}}}{\mathrm{f}_{2}} \leq 1.25, \mathrm{c}=1.0$.

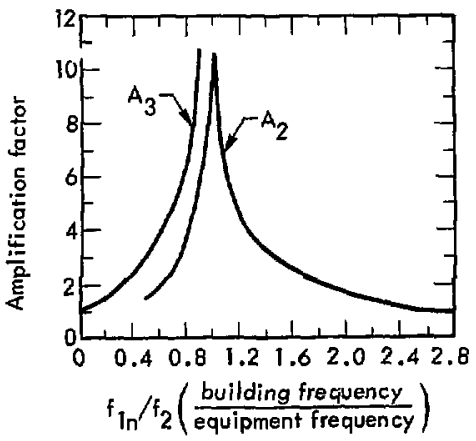

F1g. A-1. Biggs' amplification factors.

$$
\begin{aligned}
& \text { If } 1.25<\frac{\mathrm{f}_{1 \mathrm{n}}}{\mathrm{f}_{2}}<2.2 .3, \mathrm{C}=1.0 \\
& +\left(\frac{\mathrm{f}_{\mathrm{In}}}{\overline{\mathrm{F}_{2}}}-1.25\right) \\
& \times\left[\left(\sum_{n}\left(\mathrm{~J}_{1 \mathrm{n}} \mathrm{i}_{\mathrm{sn}}\right)^{2}\right)^{1 / 2}-1.0\right] \text {. } \\
& \text { If } \frac{f_{1 n}}{f_{2}} \geq 2.25 \text {, } \\
& c=\left[\sum_{n}\left(\Gamma_{1 n} \phi_{s n}\right)^{2}\right]^{1 / 2} \text {. } \\
& \text { c. If } \frac{f_{1 n}}{f_{2}} \leq 0.50, S_{2 n}=S_{2 n}^{\prime} \text {. } \\
& \text { If } \frac{F_{I n}}{f_{2}} \geq 0.90, S_{2 n}=S_{2 n}^{\prime \prime} \text {. } \\
& \text { If } 0.50<\frac{f_{1 n}}{f_{2}}<0.90 \text {, } \\
& s_{2 n}=s_{2 n}^{\prime}+\left(S_{2 n}^{\prime \prime}-s_{2 n}^{\prime}\right) \\
& \times \frac{\frac{\mathrm{f}}{\mathrm{f}} \frac{\mathrm{ln}}{\mathrm{2}}-0.50}{0 . \overline{40}} .
\end{aligned}
$$

2. When $S_{2 n}$ has been calculated for all bullding frequencies of Interest, Biggs recommends an SRSS gum to get the total spectral value, $\mathrm{S}_{2}$ :

$$
s_{2}=\left(\sum_{n} s_{2 n}^{2}\right)^{1 / 2}
$$

However, we followed the recommendation in Regulacory Guide 1,92 for closely spaced modes, just as we did In using Kapur's method. 